\title{
Breathing life into engineered tissues using oxygen-releasing biomaterials
}

\author{
Sanika Suvarnapathaki ${ }^{1,2}$, Xinchen $\mathrm{Wu}^{1,2}$, Darlin Lantigua ${ }^{1,2}$, Michelle A. Nguyen ${ }^{2,3}$ and Gulden Camci-Unal ${ }^{2,4}$
}

\begin{abstract}
Engineering three-dimensional (3D) tissues in clinically relevant sizes have demonstrated to be an effective solution to bridge the gap between organ demand and the dearth of compatible organ donors. A major challenge to the clinical translation of tissue-engineered constructs is the lack of vasculature to support an adequate supply of oxygen and nutrients post-implantation. Previous efforts to improve the vascularization of engineered tissues have not been commensurate to meeting the oxygen demands of implanted constructs during the process of homogeneous integration with the host. Maintaining cell viability and metabolic activity during this period is imperative to the survival and functionality of the engineered tissues. As a corollary, there has been a shift in the scientific impetus beyond improving vascularization. Strategies to engineer biomaterials that encapsulate cells and provide the sustained release of oxygen over time are now being explored. This review summarizes different types of oxygen-releasing biomaterials, strategies for their fabrication, and approaches to meet the oxygen requirements in various tissue engineering applications, including cardiac, skin, bone, cartilage, pancreas, and muscle regeneration.
\end{abstract}

\section{Introduction}

For many years, the reviews in this field have summarized the developments and applications of different oxygen-releasing biomaterials. Previously published examples have discussed applications of oxygen-releasing biomaterials for a limited number of tissues. However, major developments in the field have occurred more recently to expand on the current knowledge of this research area. This review provides a comprehensive overview of oxygen-releasing biomaterials, including the most recent developments and literature examples of new and innovative uses of oxygen-releasing constructs. Extensive tissue engineering applications in vitro and in vivo are elaborately discussed, including their different synthesis methods, oxygen release mechanisms and release kinetics, critical insights, and possible future applications.

Correspondence: Gulden Camci-Unal (Gulden_CamciUnal@uml.edu) ${ }^{1}$ Biomedical Engineering and Biotechnology Program, University of Massachusetts Lowell, One University Avenue, Lowell, MA 01854, USA 2Department of Chemical Engineering, University of Massachusetts Lowell, One University Avenue, Lowell, MA 01854, USA

Full list of author information is available at the end of the article.
This section provides an overview of the current challenges in the tissue engineering of 3D constructs and discusses the current approaches and biomaterials used to address these limitations. Different types of oxygenreleasing biomaterials, their synthesis and fabrication methods, and release kinetics and mechanisms are examined.

\section{Tissue engineering: current need and limitations}

Organ damage and failure are the leading causes of death globally ${ }^{1}$. According to the United States Department of Health and Human Services, more than 116,000 people in the United States were on waiting lists for organ transplants in August 2017. Since the availability of matching donors does not always meet the demand of organ transplants, there are approximately 20 deaths each day because of delayed organ transplantations ${ }^{1,2}$. In 2015, 119, 363 people in the United States were in need of an organ donation, which is double the statistics recorded in $1999^{1,3}$. Tissue engineering approaches can address the unmet demand for the replacement, repair, and regeneration of organs and tissues ${ }^{4-7}$. There has been 
remarkable success in the clinical translation of 3D tissueengineered constructs for repairing organs, such as the trachea $^{8,9}$ and lungs; ${ }^{10}$ however, multiple challenges remain unaddressed. These challenges include (i) the preservation of high cell viability postimplantation, (ii) the unwanted immune response, (iii) the obstruction of cell signaling pathways, (iv) insufficient cell proliferation, and (v) low metabolic activity within the implanted scaffolds. In addition, currently available approaches do not yield properly functioning engineered tissues because they cannot provide sustained amounts of oxygen ${ }^{11}$.

Ideally, functional tissue constructs must deliver a supply of oxygen, nutrients, and growth factors to the encapsulated cells in 3D scaffolds. These components ensure that the cells survive, proliferate, differentiate and remain metabolically active. In the human body, the primary source of nutrients for tissues is the host blood supply through the vascular system ${ }^{12}$. Generally, complete vascularization requires gradual development over time postimplantation ${ }^{12,13}$. The vascular system also includes networking for the removal of cellular wastes from tissues $^{14}$. Therefore, engineered scaffolds that can offer these chemical and structural properties tend to support high tissue viability. The use of oxygen-releasing biomaterials may overcome the oxygen diffusion limitations in organ-sized constructs ${ }^{15,16}$. Until such optimum vascularization is achieved in vivo, oxygen-releasing materials may provide an adequate oxygen supply to support the viability and metabolic function of these tissue constructs. Addressing these considerations could be a promising and an impactful solution to the clinical translation of tissue engineered constructs ${ }^{15,17}$. In conjunction with modern vascularization strategies, the removal of cellular wastes and the delivery of growth factors is also accomplished, leading to a highly biomimetic scaffold ${ }^{18,19}$.

Engineered tissues that are not within the diffusion and mass transport range for effective vascular integration do not usually survive ${ }^{11}$. There is a period of 4-6 weeks for vasculature to reach approximately $83 \%$ patency within a damaged tissue ${ }^{20}$. During this time, the capillaries and blood vessels of the host integrate and grow into the implanted engineered tissue grafts. The viability of engineered tissues is highly dependent on the amount of oxygen available during integration ${ }^{21}$. However, the solutions to support high oxygen demands and maintain high viability during this critical developmental stage are still in their infancy. Therefore, new biomaterial innovations must address the insufficient oxygen supply in current tissue engineering methodologies.

\section{Tissues with high oxygen demand: why the clinical translation of tissue engineering approaches fail?}

Without a sufficient supply of oxygen, tissues undergo necrosis and programmed cell death ${ }^{22-25}$. The tendency to undergo necrotic death is especially evident for cells and tissues with high metabolic activity and oxygen demand. Maintaining the viability of such tissues (e.g., cardiac, pancreas, muscle) is a challenge that has prolonged the clinical translation of engineered tissues for the treatment of diseased or damaged organs ${ }^{11}$. Perfusion in conjunction with convective diffusion mechanisms is a method to improve oxygen availability for engineered tissues but has limited success ${ }^{26}$. The extent and speed of optimum vascularization in tissue-engineered grafts depends on multiple factors: scaffold design, porosity, interconnectivity, the influence of growth factors, and paracrine signaling, which facilitates tissue development ${ }^{27-30}$. These factors motivate the development of functional materials that mimic the in vivo microenvironments and facilitate the functional development and integration of engineered tissues ${ }^{31}$. As a result, innovative approaches to fabricate thick and vascularized constructs are currently studied for the clinical translation of engineered tissues.

\section{Current strategies for the survival of tissue-engineered constructs with high oxygen demand}

For tissues with greater oxygen demands, various approaches have been utilized and shown to either increase the oxygen content or functionality of tissue constructs. Supplementing the cell media with oxygen carriers has enabled the increase in oxygen content in tissue engineered constructs ${ }^{32}$. Other technologies, such as perfusion bioreactors, can culture cells in welloxygenated environments. To improve vasculature and tissue viability, cell-laden samples have been treated with growth factors, such as vascular endothelial growth factor (VEGF). Although promoting vasculature is important, the effectiveness of this strategy is limited by the inhomogeneous incorporation of growth factors in $3 \mathrm{D}^{33}$. Microfluidic techniques for the fabrication of vascular networks within 3D scaffolds also have allowed the guided development of blood vessels. Despite the in vitro success of microfluidic approaches, the resolution of microfabrication techniques was not optimal ${ }^{34,35}$. Other studies have attempted to incorporate angiogenic cells into scaffolding matrices to promote rapid neovascularization ${ }^{36-39}$. The use of terminally differentiated endothelial or human umbilical vein endothelial cells (HUVECs) has been shown to have poor vasculature development both in vitro and in vivo ${ }^{40}$. To facilitate blood vessel formation, some approaches have also used porous interconnected scaffolds that release growth factors ${ }^{41-44}$. Until uniform blood vessel networks are formed, the integration with the host vasculature is incomplete and oxygen availability is restricted. Given the extensive timeline for vasculature integration, oxygen demands must be provided through external means. Therefore, biomaterial scaffolds must 
both consider the necessary networking and, importantly, the oxygen supply required. Recent progress in this research has recently shifted to biomaterials that can provide this oxygen supply over extended periods of time.

\section{Approaches to engineer oxygen-releasing biomaterials}

The transition from refining vascularization techniques to engineering oxygen-releasing biomaterials has seen significant progress over the past decade ${ }^{11}$. Oxygenreleasing biomaterials can be fabricated through the incorporation of solid peroxides, liquid peroxides, and fluorinated compounds into the scaffold polymer. These scaffolds can serve as 2D tissue culture substrates or be used in the 3D encapsulation of cells. Inorganic solid peroxides, such as calcium and sodium peroxides, liquid peroxides, and perfluorocarbons, have been used to supply oxygen to cells ${ }^{45-47}$. The most commonly used techniques to incorporate compounds for oxygen delivery are adsorption onto fiber-based scaffolds, 3D encapsulation in polymers, and incorporation into hydrogel networks ${ }^{16,48,49}$. Micro- and nanoparticles of solid peroxides (e.g., calcium, magnesium, and sodium peroxide) interact with water and undergo hydrolytic degradation to release oxygen $^{50}$. The introduction of these particles has shown significant in vitro and in vivo successes. This review summarizes the different types of materials used to obtain the controlled release of oxygen in engineered tissues to prevent cell death due to hypoxic stress. Table 1 outlines the different types of oxygen-releasing compounds that are used in tissue engineering applications and their corresponding oxygen-release mechanisms.

\section{Oxygen-releasing biomaterials: advantages, synthesis, composition, and characterization}

The need for oxygen-releasing materials has led to the development of new substrates that release oxygen in a sustained and controlled manner. Controlling the oxygen- release kinetics can significantly influence cell differentiation, viability, and proliferation. Solid inorganic peroxides, liquid peroxides, and fluorinated compounds can be used for sustained oxygen release and maintain high cell viability in the tissue construct ${ }^{21}$. The strategy of doping scaffolding polymers with oxygen-releasing peroxides and fluorinated compounds has been increasingly used to enhance the viability of tissue constructs ${ }^{11}$. In this section, we discuss the different types of solid and liquid oxygen-releasing reagents, approaches to incorporate these reagents into biomaterials, and their oxygengenerating mechanisms.

\section{Solid inorganic peroxides}

Solid inorganic peroxides have been successfully used as oxygen-releasing materials in vitro and in vivo. The most commonly used solid peroxides are sodium, calcium, and magnesium peroxides ${ }^{16,50,51}$. The main mechanism behind the oxygen release in these inorganic compounds is hydrolysis. When nano/microparticles of calcium, sodium, and magnesium peroxide interact with water, the particles undergo hydrolytic decomposition, as shown in the following equations ${ }^{52-54}$.

(Calcium peroxide) $\mathrm{CaO}_{2}(\mathrm{~s})+2 \mathrm{H}_{2} \mathrm{O} \rightarrow \mathrm{Ca}(\mathrm{OH})_{2}(\mathrm{~s})+$ $\mathrm{H}_{2} \mathrm{O}_{2}$

(Magnesium peroxide) $\mathrm{MgO}_{2}(\mathrm{~s})+2 \mathrm{H}_{2} \mathrm{O} \rightarrow \mathrm{Mg}$ $(\mathrm{OH})_{2}(\mathrm{~s})+\mathrm{H}_{2} \mathrm{O}_{2}$

(Sodium percarbonate) $\left(\mathrm{Na}_{2} \mathrm{CO}_{3}\right)_{2} \cdot 3 \mathrm{H}_{2} \mathrm{O}_{2} \rightarrow 4 \mathrm{Na}^{+}+$ $2 \mathrm{CO}_{3}{ }^{-2}+3 \mathrm{H}_{2} \mathrm{O}_{2}$

$2 \mathrm{H}_{2} \mathrm{O}_{2} \rightarrow \mathrm{O}_{2}+2 \mathrm{H}_{2} \mathrm{O}$

Solid inorganic peroxides have been used to support cell growth, survival, tissue regeneration, and bioremediation. Among these materials, calcium peroxide has been shown to produce the highest amount of oxygen in a variety of applications ${ }^{55}$. The amount of oxygen released by inorganic solid peroxides depends on their solubility coefficients. The equilibrium coefficients of calcium and

Table 1 Types of oxygen-generating compounds and their oxygen-release mechanisms, oxygen-release potentials, and common applications in tissue engineering

\begin{tabular}{|c|c|c|c|}
\hline Compound & $\begin{array}{l}\text { Release mechanism and oxygen } \\
\text { delivery system }\end{array}$ & $\begin{array}{l}\text { Amount of oxygen } \\
\text { released }\end{array}$ & Common applications \\
\hline Calcium peroxide & Hydrolytic decomposition & $22+/-3.3 \mathrm{mg} / \mathrm{L}^{55}$ & $\begin{array}{l}\text { Cardiovascular tissue engineering }{ }^{27} \text {, } \\
\text { wound healing }^{54} \text {, bone tissue } \\
\text { engineering }^{118}\end{array}$ \\
\hline Magnesium peroxide & Hydrolytic decomposition & $44.38 \mathrm{mg} / \mathrm{L}^{55}$ & \\
\hline Sodium percarbonate & Hydrolytic decomposition & $31+/-2.0 \mathrm{mg} / \mathrm{L}^{55}$ & \\
\hline Hydrogen peroxide & $\begin{array}{l}\text { Enzymatic decomposition in } \\
\text { presence of catalase and hydrolysis }\end{array}$ & $\begin{array}{l}12 \mathrm{~mL} \text { per } 1 \mathrm{~g} \text { of } \mathrm{H}_{2} \mathrm{O}_{2} \text {, i.e., } \\
17.148 \mathrm{mg} / \mathrm{L}^{119}\end{array}$ & $\begin{array}{l}\text { Pancreatic islet tissue engineering }{ }^{120} \\
\text { cardiac tissue engineering }^{26}\end{array}$ \\
\hline $\begin{array}{l}\text { Fluorinated compounds such as } \\
\text { perfluorodecalin and perflubron }\end{array}$ & Diffusion & $\begin{array}{l}40 \mathrm{ml} \text { per } 100 \mathrm{ml} \text { of } \mathrm{O}_{2} \text {, i.e., } \\
57.16 \mathrm{mg} / \mathrm{L} \text { per } 100 \mathrm{~mL} \mathrm{O}_{2}^{121}\end{array}$ & $\begin{array}{l}\text { Muscle regeneration }{ }^{34} \text {, intervertebral disc } \\
\text { regeneration }{ }^{106} \text {. }\end{array}$ \\
\hline
\end{tabular}


magnesium peroxide are $9.8 \times 10^{-11}$ and $1.8 \times 10^{-11}$, respectively ${ }^{55}$. Calcium and magnesium peroxide have low solubility coefficients $\left(1.65 \mathrm{~g} / \mathrm{L}\right.$ at $20^{\circ} \mathrm{C}$ and $0.86 \mathrm{~g} / \mathrm{L}$ at $18{ }^{\circ} \mathrm{C}$, respectively) ${ }^{55}$. Based on these values, calcium peroxide has a higher oxygen-generation potential than magnesium peroxide ${ }^{55-58}$. Magnesium peroxide produces the lowest amount of oxygen among solid peroxides ${ }^{55}$ with a content purity of $15-20 \%$ by weight ${ }^{11}$. This effect is mainly due to the low solubility of magnesium peroxide in water, which reduces the rate of oxygen formation. While these approaches facilitate oxygen generation, burst release may occur at uncontrolled rates. This release behavior is especially found in hydrogels that have solid peroxides encapsulated without any hydrophobic barriers ${ }^{11}$. Table 2 summarizes the solubility coefficients of different solid inorganic peroxides.

For more controlled rates of oxygen release, hydrophobic substrates can be utilized for the encapsulation of oxygen-releasing particles. Hydrophobic materials, such as polydimethylsiloxane (PDMS) and poly(D, L-lactidecoglycolide) (PLGA) act as barriers to reduce the rate of hydrolysis of the oxygen-releasing particles and help establish a more controlled rate of oxygen release ${ }^{59,60}$. Conversely, if the oxygen-releasing particles are surrounded by hydrophilic polymers, then the material allows for the rapid diffusion of water molecules into the 3D matrix, which can dramatically increase the rate of oxygen generation ${ }^{11,61}$. The rate at which oxygen is released from the solid peroxides is also dependent on other environmental factors, such as the $\mathrm{pH}$, temperature, and peroxide-to-water ratio.

Solid inorganic peroxides readily undergo hydrolytic decomposition upon reaction with the water content in the biomaterial. The solubility of peroxide is a factor that can affect the overall oxygen-release kinetics and quantities in implanted constructs ${ }^{16}$. However, the release kinetics of solid inorganic peroxides are controlled by changing the temperature, $\mathrm{pH}$, purity, and solubility of the compound. Consequently, the oxygen-release kinetics can be tailored to a wide spectrum of tissue engineering applications. The caveat is that some solid inorganic peroxides, such as calcium peroxide, can produce reactive oxygen species during hydrolytic decomposition. These byproducts are potentially harmful to the cells encapsulated in the scaffolding material. As an improvement, the addition of enzymes can assist in the decomposition reaction. Specifically, the catalase enzyme can decompose the intermediate hydrogen peroxide into water and oxygen. This intermediate step eliminates any potential cytotoxic reactive oxygen species ${ }^{16}$.

\section{Liquid peroxides}

In addition to solid oxygen-releasing reagents, liquid peroxides have been used in various biomedical
Table 2 The solubility coefficients of the solid inorganic peroxides used to engineer oxygen-releasing compounds are summarized

\begin{tabular}{ll}
\hline Solid inorganic peroxides & Solubility coefficients in water \\
\hline Calcium peroxide & $1.65 \mathrm{~g} / \mathrm{L}$ at $20^{\circ} \mathrm{C}^{56,122}$ \\
Magnesium peroxide & $0.086 \mathrm{~g} / \mathrm{L}$ at $18^{\circ} \mathrm{C}^{123}$ \\
Sodium percarbonate & $120 \mathrm{~g} / \mathrm{L}$ at $20^{\circ} \mathrm{C}^{124}$ \\
\hline
\end{tabular}

applications. The higher solubility of liquid peroxides in water permits rapid oxygen release. Hydrogen peroxide is a liquid compound that can release oxygen upon decomposition into oxygen and water. In the human body, the enzyme catalase, present in the liver and blood, breaks down hydrogen peroxide into water and oxygen ${ }^{62}$. Although the actual role of catalase in the oxygen-release process is unclear, decomposition is suggested to take place through the following reactions:

$$
\begin{array}{r}
\mathrm{H}_{2} \mathrm{O}_{2}(\mathrm{aq})+2 \mathrm{Fe}^{3+}(\mathrm{aq}) \rightarrow \mathrm{O}_{2}(\mathrm{~g})+2 \mathrm{Fe}^{2+}(\mathrm{aq})+2 \mathrm{H}^{+}(\mathrm{aq})^{22} \\
\left.\mathrm{H}_{2} \mathrm{O}_{2}(\mathrm{aq})+2 \mathrm{Fe}^{2+}(\mathrm{aq})\right)+2 \mathrm{H}^{+}(\mathrm{aq}) \rightarrow 2 \mathrm{H}_{2} \mathrm{O}(\mathrm{l})+2 \mathrm{Fe}^{3+} \\
(\mathrm{aq})^{63}
\end{array}
$$

In the absence of catalase, cytotoxic side products of this reaction, such as free hydroxyl radicals, are often generated and detrimental to the cells ${ }^{64}$. Liquid peroxides have also been used to control the efficiency of oxygen release in cell encapsulation approaches. For example, hydrogen peroxide was microencapsulated within PLGA and coated with a secondary layer made of an alginate hydrogel ${ }^{64}$. Then, catalase was chemically modified into the alginate backbone. The hydrogen peroxide is released from the PLGA and diffuses into the alginate layer. The alginate spheres containing catalase assisted in the decomposition of hydrogen peroxide into oxygen and water without generating harmful radicals that may have otherwise influenced cell viability ${ }^{64}$. Other strategies that used hydrogen peroxide as an oxygen source have demonstrated oxygen release over a two-week period in which successful cell differentiation was induced ${ }^{11}$. Figure 1 represents the chemical structures of different oxygen-releasing compounds. The commonly used solid peroxides, liquid peroxides, and fluorinated oxygenreleasing compounds are shown. The listed solid and liquid peroxides undergo rapid hydrolytic decomposition and release oxygen as a byproduct. The fluorinated compounds have a high oxygen-carrying capacity and release oxygen by diffusion mechanisms.

The rate of oxygen release is dependent on the efficiency of the liquid peroxide used in the application. In the absence of enzymes, liquid peroxides, such as hydrogen peroxide, can generate cytotoxic side products. To mitigate this issue, enzymes can assist in the conversion of hydrogen peroxide to water and oxygen. Specifically, 
a

$\mathrm{HO}-\mathrm{OH}$
hydrogen peroxide

e

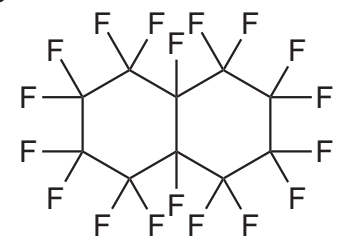

perfluorodecalin
C<smiles>[O-]O[O-]</smiles>
magnesium peroxide d<smiles></smiles>

sodium percarbonate b

calcium peroxide

f

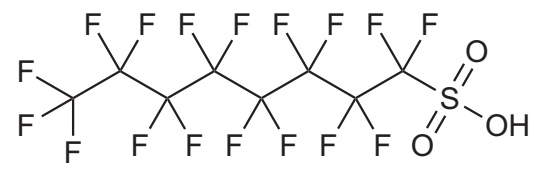

perfluorooctanesulfonic acid

Fig. 1 Chemical structures of prominent oxygen-releasing compounds. a Hydrogen peroxide, $\mathbf{b}$ calcium peroxide, $\mathbf{c}$ magnesium peroxide, d sodium percarbonate, e perfluorodecalin, and $\mathbf{f}$ perfluorooctanesulfonic acid (PFOS)

catalase is a useful enzyme to achieve this result and contains iron and organic functional groups that enhance the oxygen-release capabilities. Moreover, catalase has a high turnover efficiency, which can improve the potency of oxygen-releasing compounds ${ }^{11}$.

\section{Fluorinated compounds}

Fluorinated compounds have functioned as oxygen carriers in numerous applications in cosmetics, drug delivery, protein stabilization, and organ preservation where the oxygen content is critical for the effectiveness of the product or the process ${ }^{65}$. In the last decade, the use of fluorinated compounds in tissue culture applications and their effectiveness in supporting the high oxygen demand in tissues in vitro and in vivo have become widely used in biomedical research ${ }^{66}$. In particular, perfluorodecalin, a fluorocarbon, in water emulsions have acted as an oxygen carrier and prevented ischemia after surgical procedures ${ }^{65}$. The surface chemistry of fluorinated surfactants, such as perfluorooctanesulfonic acid (PFOS) and perfluorooctanoic acid (PFOA), have demonstrated greater surface activity than that of their fluorocarbon analogs, such as perfluoroalkylated amine oxide $^{65}$. The molecular structures of these surfactants, such as the fluorocarbon/hydrocarbon amphiphile $\mathrm{FnHm}$ (i.e., $\mathrm{C}_{6} \mathrm{~F}_{13} \mathrm{C}_{10} \mathrm{H}_{21}$ ), enable these compounds to have a self-assembling nature and form highly stable emulsions and gels. This feature allows control over the diffusion and oxygen-release kinetics, a desired property of oxygenreleasing materials. Some fluorinated surfactants, such as perfuoromethyl-cyclohexylpiperidin $\left(\mathrm{C}_{12} \mathrm{~F}_{23} \mathrm{~N}\right)$, have demonstrated high potential to treat tissues in hypoxic environments in cardiovascular tissue engineering, tumor treatment, and surgical applications. However, these treatments are not approved by the Food and Drug Administration (FDA) and are currently in clinical trial stages ${ }^{67}$. Table 3 summarizes the most common forms of fluorinated compounds and their applications as oxygen carriers.

The molecular structures of these surfactants, such as the fluorocarbon/hydrocarbon amphiphile $\mathrm{FnHm}$ (i.e., $\mathrm{C}_{6} \mathrm{~F}_{13} \mathrm{C}_{10} \mathrm{H}_{21}$ ) enables them to have a self-assembling nature and form highly stable emulsions and gels. This feature allows greater control over diffusion and oxygenrelease kinetics. In applications where there are limitations in oxygen diffusion or oxygen, there is typically an overall low cell viability, especially in organ-size constructs ${ }^{67}$. Fluorinated emulsions have been demonstrated to support these oxygen demands and enhance cell viability. Some fluorinated surfactants, such as perfuoromethyl-cyclohexylpiperidin, have shown high potential to treat tissues in hypoxic environments in cardiovascular tissue engineering, tumor treatment, and surgical applications $^{67}$. However, these treatments are not approved by the Food and Drug Administration (FDA), which can delay clinical transition stages ${ }^{67}$. Table 3 summarizes the most common forms of fluorinated compounds and their applications as oxygen carriers. Fluorinated compounds, such as perfluorocarbons (PFCs), can dissolve large amounts of oxygen and act as oxygen carriers. In hydrogels, PFCs have been utilized in the form of aqueous emulsions or encapsulated directly in polymeric biomaterials. This incorporation releases the dissolved oxygen through diffusion. PFCs are denser materials that are advantageous in tissue applications that require an oxygen-rich environment ${ }^{11,68,69}$.

\section{Applications of oxygen-releasing biomaterials in tissue engineering}

Different types of oxygen-releasing chemistries achieve distinct oxygen-release characteristics. The cells in the body have varying oxygen tensions and saturation 
Table 3 Fluorinated compounds used for oxygen release and delivery

\begin{tabular}{|c|c|c|c|c|}
\hline $\begin{array}{l}\text { Form of the fluorinated } \\
\text { compound }\end{array}$ & $\begin{array}{l}\text { Type of the fluorinated } \\
\text { compound }\end{array}$ & $\begin{array}{l}\text { Properties of the } \\
\text { fluorinated compound }\end{array}$ & $\begin{array}{l}\text { Applications in tissue } \\
\text { engineering }\end{array}$ & References \\
\hline Neat fluorocarbons & $\begin{array}{l}\text { Fluorocarbons mixed with } \\
\text { stabilizers: FnHm diblock } \\
\text { solubilizers }\end{array}$ & $\begin{array}{l}\text { Oxygen transport, fluidity, } \\
\text { positive diffusion coefficient }\end{array}$ & $\begin{array}{l}\text { Oxygen diffusion using liquid } \\
\text { medium, tissue cultures in } \\
\text { beta cell transplantation }\end{array}$ & $125-128$ \\
\hline $\begin{array}{l}\text { Fluorocarbons in water } \\
\text { emulsions }\end{array}$ & $\begin{array}{l}\text { Fluorocarbons mixed with } \\
\text { stabilizers: FnHm diblock } \\
\text { solubilizers }\end{array}$ & $\begin{array}{l}\text { Oxygen transport, solubility, } \\
\text { stability }\end{array}$ & $\begin{array}{l}\text { Injectable carriers of oxygen, } \\
\text { perisurgical applications, } \\
\text { cardiovascular bypass } \\
\text { surgeries to prevent hypoxia, } \\
\text { organ preservation }\end{array}$ & 129 \\
\hline $\begin{array}{l}\text { Fluorocarbon gels with a } \\
\text { disperse fluorocarbon phase } \\
\text { (HIPRE) }\end{array}$ & $\begin{array}{l}\text { Fluorocarbons, } \\
\text { Fluorosurfactants }\end{array}$ & $\begin{array}{l}\text { Adjustable viscosity, oxygen } \\
\text { permeation, repellant to } \\
\text { hydrophilic and lipophilic } \\
\text { materials }\end{array}$ & $\begin{array}{l}\text { Skin and wound healing, } \\
\text { barrier creams }\end{array}$ & 130 \\
\hline $\begin{array}{l}\text { Fluorocarbons in water micro } \\
\text { emulsions }\end{array}$ & $\begin{array}{l}\text { Fluorocarbons, } \\
\text { Fluorosurfactants FnHm } \\
\text { diblocks }\end{array}$ & Stability and small particle size & $\begin{array}{l}\text { Oxygen delivery, drug } \\
\text { delivery, contrast agents }\end{array}$ & 131 \\
\hline $\begin{array}{l}\text { Fluorinated vesicles, tubules, } \\
\text { and fibers }\end{array}$ & Fluorinated ligands & Chelating properties, stability & $\begin{array}{l}\text { lonic delivery, permeation of } \\
\text { oxygen. }\end{array}$ & 132 \\
\hline
\end{tabular}

Modified and reprinted with permission from Reiss et al. ${ }^{68}$ Copyright 1998, Elsevier

requirements for their survival, differentiation, functionality and growth. This section discusses how different oxygen-releasing biomaterials are used in applications for cardiovascular tissue engineering, islet transplantation, wound healing, skin regeneration, muscle regeneration, intervertebral disc regeneration, and preventing biofilm formation.

\section{Cardiovascular tissue engineering}

The challenges faced in the clinical translation of cardiovascular tissue engineered approaches include the lack of an ideal cell population, the inability to engineer cardiac tissue mimetic matrices, the inability to induce proper vascularization, and limitations in vascularization ${ }^{70-72}$. These factors are particularly important for the generation of physiologically-relevant $3 \mathrm{D}$ constructs ${ }^{27}$. Ensuring the oxygenation of engineered scaffolds is crucial for tissue viability and integration in vivo ${ }^{30}$. Control over oxygen-release kinetics can be achieved through the encapsulation of oxygengenerating materials in hydrogels and other polymeric materials at different concentrations. Due to the highly reactive nature of calcium peroxide, monitoring the oxygen-release rate can determine viability and induce cardiac stem cell differentiation ${ }^{49}$. Long-term cardiac cell cultures require sustained oxygen generation, which has been explored more recently with the addition of hydrophobic barriers.
Free radicals are considered a potential source of cytotoxicity in many 3D-encapsulation strategies. These radicals generated from the hydrolysis of solid peroxides could damage cardiac cells ${ }^{16}$. As an alternative approach, liquid peroxides, such as hydrogen peroxide, have been used in some cardiac tissue engineering applications to improve cell viability and provide sustained oxygen release with hydrophobic barriers. Figure 2 shows the use of liquid peroxides with a hydrophobic barrier to fabricate biomaterials that provides sustained oxygen release over time $^{49}$. In a study by $\mathrm{Li} \mathrm{Z}$ et al., hydrogen peroxide and poly (2-vinlypyrridione) (PVP) were encapsulated in PLGA microparticles, which were then incorporated into a thermosensitive hydrogel made from hydroxyethyl methacrylate oligo (hydroxybutyrate), N-isopropylacrylamide (NIPAAm), and acrylic acid (AAC). Cardiospherederived cells (CDCs) were encapsulated in this hybrid hydrogel. The results demonstrated the homogeneous distribution of cells throughout the 3D structure. The cell viability significantly increased in the presence of the oxygen-generating hydrogels placed in a hypoxic environment for up to two weeks (Fig. 2) ${ }^{18,49}$.

Figure 3 shows another study in which primary human coronary artery smooth muscle cells (HCASMCs) were seeded onto scaffolds composed fluorinated zeolite (FZ) particles embedded in poly(carbonate-urethane) (PCU) (Fig. 3$)^{73}$. These zeolite particles acted as oxygen vectors enabling enhanced oxygen delivery to the seeded cells. 

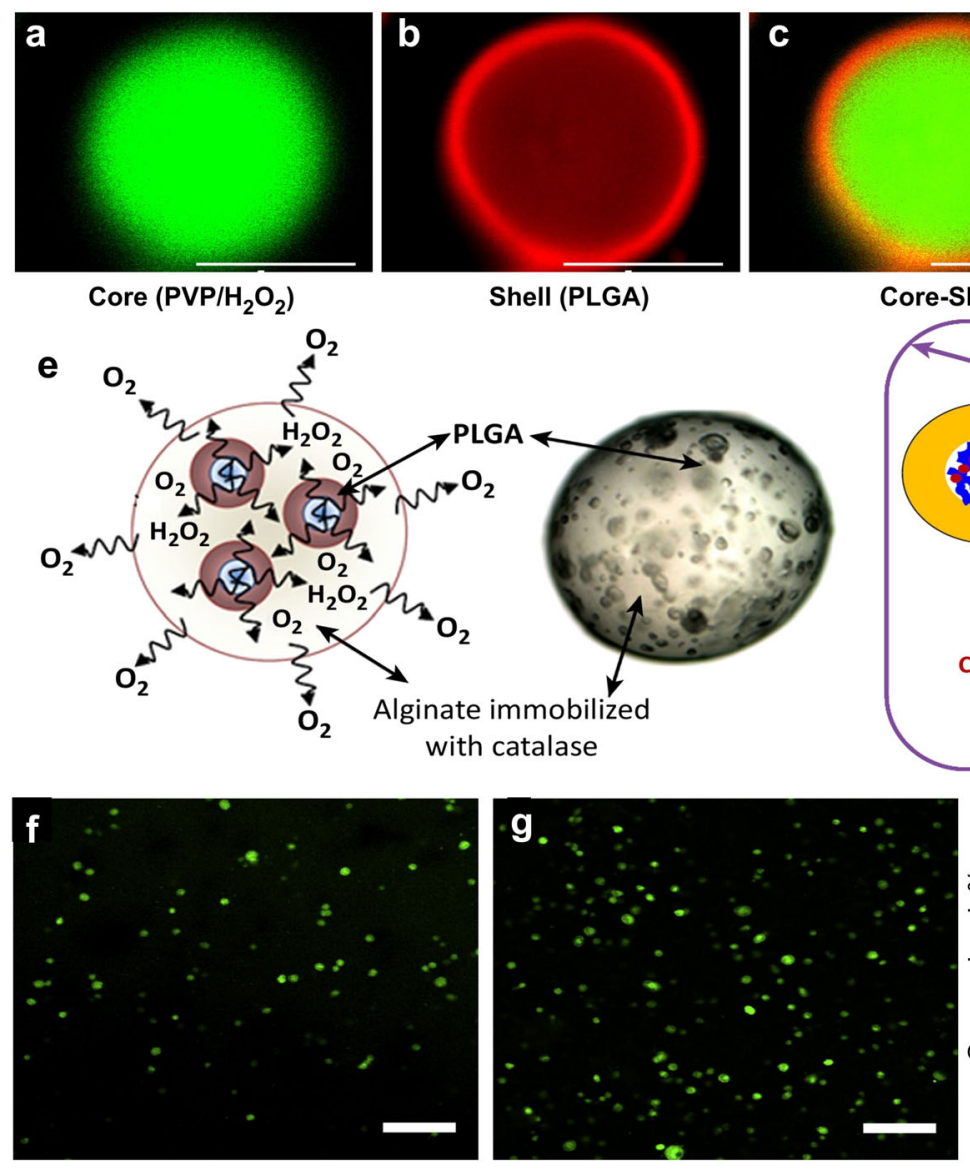

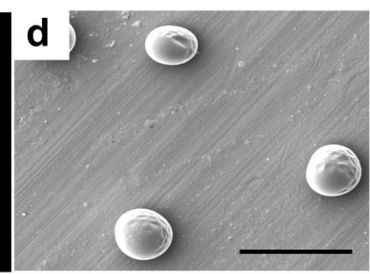

Core-Shell

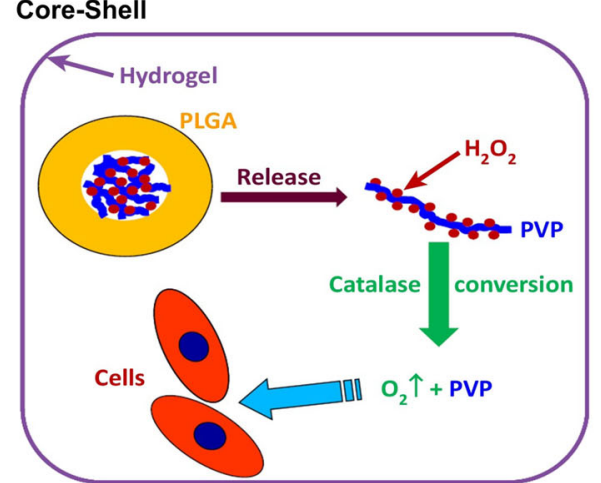

Fig. 2 The PVP/ $\mathrm{H}_{2} \mathrm{O}_{2}$ core shell oxygen-releasing design to encapsulate cardiosphere-derived cells (CDCs). a-c Confocal images of the polymer core PVP/ $/ \mathrm{H}_{2} \mathrm{O}_{2}$. Scale bar: $5 \mu \mathrm{m}$. d SEM image of oxygen-releasing microspheres. Scale bar $=10 \mu \mathrm{m}$. e Schematic representation of the structure and oxygen-release mechanism of the PVP/ $\mathrm{H}_{2} \mathrm{O}_{2}$ microspheres for different ratios of $\mathrm{H}_{2} \mathrm{O}_{2} / \mathrm{PVP}$ to support the survival and differentiation of CDCs under hypoxic conditions. $\mathbf{f}$ CellTracker Green CMFDA (5-chloromethylfluorescein diacetate) labeling of CDCs analyzed on day 14 without oxygen release and $\mathbf{g}$ CMFDA staining of CDCs with oxygen-releasing microspheres containing $\mathrm{H}_{2} \mathrm{O}_{2} / \mathrm{PVP}$ core-shells. $\mathbf{h}$ Release kinetics of the PVP/ $\mathrm{H}_{2} \mathrm{O}_{2}$ microspheres for different ratios of $\mathrm{H}_{2} \mathrm{O}_{2} /$ PVP. Scale bar: $100 \mu \mathrm{m}$. Modified and reprinted with permission from Li.Z et al. ${ }^{49}$ Copyright 2012 , Elsevier

The PCU-FZ scaffolds were coated with fibronectin for cell attachment and cultured for different time points: 4 , 7 , and 14 days $^{73}$. Significantly higher cell proliferation and infiltration depths were observed in the PCU-FZ scaffolds than in the non-FZ PCU scaffolds ${ }^{73}$. Unlike blood, where oxygen is chemically bonded to hemoglobin, soluble oxygen can be released from the perfluorinated molecules whenever required. Figure 3 represents the viability and growth of the HCASMCs on PCU, PCU-FZ, and non-FZ PCU scaffolds. The results indicated that the PCU-FZ scaffolds supported higher cell proliferation than did the pure PCU scaffolds. The oxygen release increased as the fluorinated zeolite content increased. Based on the results of these studies, peroxides and fluorinated compounds incorporated into polymeric materials can enhance cell viability, growth, proliferation, and differentiation for cardiovascular tissue engineering applications.

\section{Pancreatic tissue engineering}

The transplantation of isolated islets of Langerhans is a potential treatment option for Type 1 Diabetes Mellitus $(T 1 D)^{74}$. Numerous strategies have sought methods to induce angiogenesis after transplantation ${ }^{75}$. However, the introduction of angiogenic growth factors produced by the transplanted islets is insufficient to sustain the high oxygen demand immediately postimplantation. The existing approaches to maintaining the viability of transplanted islets use external oxygen supplies. Specifically, to suffice this demand, the patient is injected with oxygen delivery probes. The 3D tissue construct includes proangiogenic factors, such as vascular endothelial growth factor (VEGF). Similarly, prevascularization of the engineered constructs is also implemented to support tissue construct viability and oxygen demands ${ }^{74}$. Nevertheless, these current strategies have limitations in the efficiency 


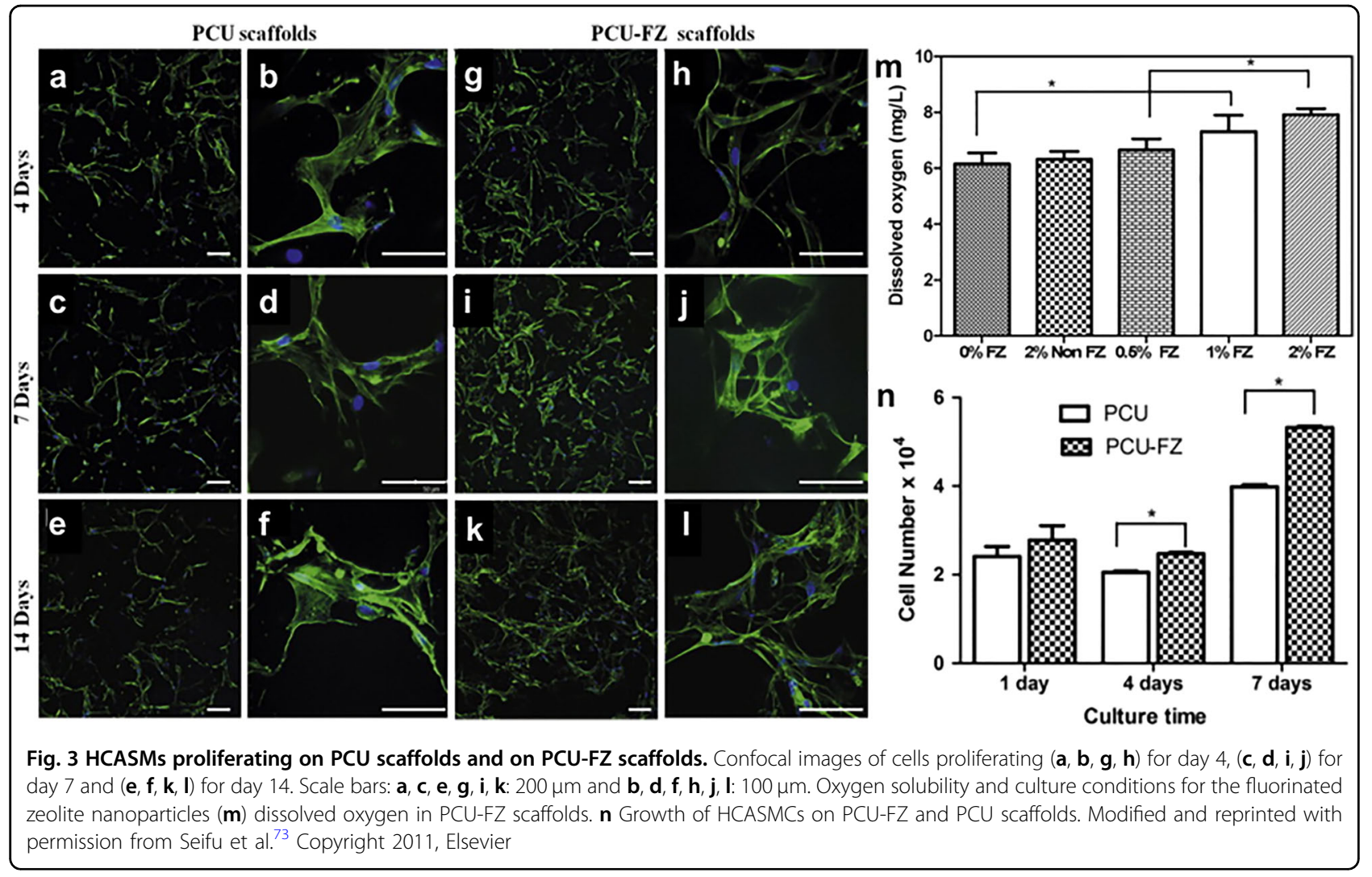

of growth factor incorporation and do not guarantee high cell viability and functionality ${ }^{76}$. The development of oxygen-releasing scaffolds that improve tissue viability and functionality after transplantation has been explored and has shown promising results. In one study, oxygengenerating microparticles (MP) were engineered using a core-shell approach. The core comprised $\mathrm{PVP} / \mathrm{H}_{2} \mathrm{O}_{2}$, which was formed inside a PLGA shell (Fig. 4$)^{77}$. Figure 4 shows the structure of the microparticle surfaces, which were further coated with the enzyme catalase to ensure high cell viability. In the presence of catalase, hydrogen peroxide decomposed to oxygen and water after its release from the microparticle core. The microparticles were embedded in a nanofibrous scaffold made of collagen with a fibrin heparin/VEGF frame acting as the delivery system. High oxygen release between $0.83 \pm 0.15$ and $0.06 \pm$ $0.05 \mathrm{mg} / \mathrm{L}$ was observed over a 14-day period ${ }^{77}$. The viability of isolated rat islets was monitored under both hypoxic and oxygen-generating conditions using MTS and LDH activity assays (Fig. 4). In the presence of the oxygen-generating microparticles, there was an increase in cell function, and cell lysis was not present ${ }^{77}$.

Solid oxygen-releasing compounds, such as sodium percarbonate (SPO) and calcium peroxide (CPO), have also been utilized to provide supplemental oxygen to pancreatic islets. In this approach, SPO particles were incorporated into polydimethylsiloxane (PDMS) in Petri dishes to generate $1 \mathrm{~mm}$-thick films. Then, another $1 \mathrm{~mm}$-thick layer of PDMS was poured and cured on top of the SPO film. Next, islet cells were seeded onto these oxygen-generating polymer layers to provide additional oxygen for 4 days $^{45}$. Similarly, CPO particles were coencapsulated inside alginate microspheres. The CPO particles released oxygen via hydrolytic decomposition and enhanced islet viability. MTS assays indicated doubled cell viability in these oxygen-generating biomaterials ${ }^{45}$. Similarly, a composite oxygen-generating polymer was also synthesized to increase oxygen availability during the early islet engraftment period. Figure 5 shows the material consisting of a $\mathrm{CPO}$ encapsulating PDMS composite. Mouse insulinoma 6 (MIN6) cells were cultured overnight in a hypoxic environment with and without the PDMS$\mathrm{CPO}$ discs $^{50}$. The viability and metabolic activity of the MIN6 beta cells were higher in the presence of the oxygen-generating PDMS-CPO discs than in the absence of CPO. Figure 5 shows the oxygen-release kinetics observed in the in vitro culture of the MIN-6 cells. The positive effect on metabolic activity included sustained oxygen release over a 40-day period. These results were shown through an MTT assay conducted over a 25-day period. Overall, the results indicate that the long-term viability and proliferation of the beta cells after 3 weeks in 


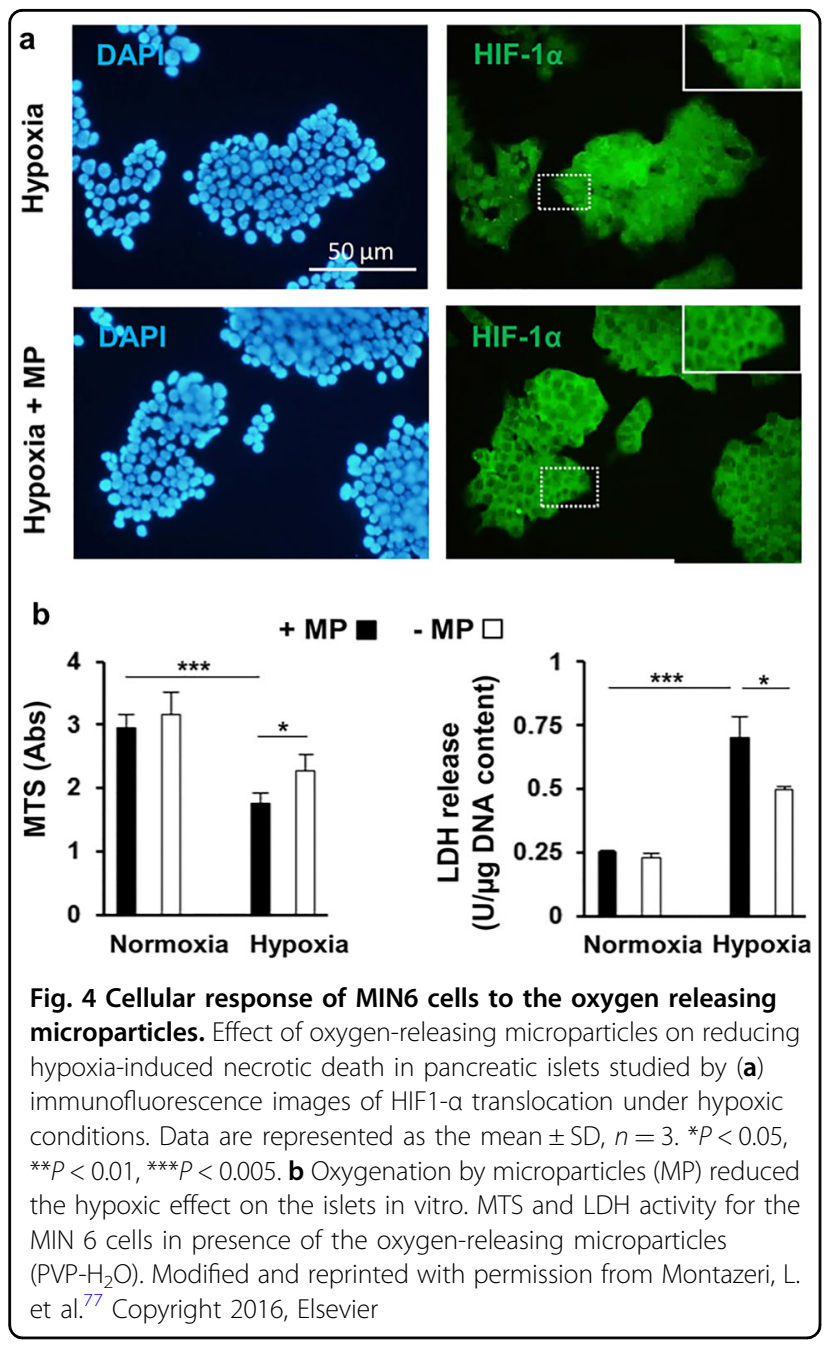

cell culture were substantially higher on substrates with the oxygen-generating polymers than in control substrates where the oxygen-releasing compounds were absent (Fig. 5).

\section{Wound healing}

Wounds are common forms of injury in tissues with most acute wounds healing properly without medical interventions. However, some of the chronic wounds will have delayed healing or lead to unhealed open wounds or ulceration $^{78,79}$. The blood supply is an essential component in wound healing that aids in the formation of connective tissue. In some cases, the local blood supply is limited, which inhibits the migration of inflammatory cells and proliferation of endothelial cells in wounds ${ }^{80}$. The formation of vasculature, however, is an extensive process in which injured tissue may be highly susceptible to necrosis ${ }^{81}$. Wound oxygenation treatment is a strategy to prevent necrosis and facilitate proper wound healing. Oxidation therapy has proven to be effective for hypoxic tissues $^{82}$. Oxygen can improve the proliferation of fibroblasts by inducing these cells to produce more collagen, which enhances the formation of connective tissue $^{79,83}$. Conventional therapies, such as hyperbaric oxygen therapy, have been used to treat a variety of open wound types, including diabetic ulcers. In combination with other current treatments, these methods in medical practice have shown therapeutic benefits ${ }^{69,84-87}$. Oxygenreleasing materials have been employed in wound healing applications in the form of fluorinated methacrylamide chitosan and biodegradable hydrogels ${ }^{79}$. In this study, methacrylamide chitosan modified with perfluorocarbon chains (MACF) hydrogels were placed in phosphatebuffered saline (PBS) and saturated with up to $100 \%$ oxygen for $10 \mathrm{~min}$ Then, these hydrogels were placed on dissolved oxygen sensors in a closed container. Oxygen saturation was measured at three time points $(1,24$, and $48 \mathrm{~h})$. The results showed that the hydrogels could effectively deliver and release oxygen in vitro ${ }^{79}$. The hydrogel was then implanted onto a rat skin wound for 8 days. Histology and immunohistochemistry analyses demonstrated an enhanced wound healing process in the presence of the oxygen-releasing hydrogel ${ }^{79}$.

In another study, a cost-effective and portable device was developed to release oxygen to a targeted damaged tissue area without affecting other undamaged tissues ${ }^{78}$. The oxygen delivery device consisted of parchment paper and PDMS, on which microfluidic channels were fabricated. Hydrogen peroxide was introduced in the PDMS channels to release oxygen to the paper, which contained manganese dioxide embedded in catalytic regions. The microfluidic channels that included the oxygen-releasing component released oxygen at a controlled rate. The results of the in vitro study showed high cell viability in the presence of oxygen-releasing reagent. In some cases, hypoxic wounds can develop into ulcerations that do not heal efficiently. Diabetes is the most common reason for foot ulcerations, which can directly impact the mobility and overall quality of life of patients ${ }^{88}$. In another study, PVP and polyvinyl alcohol (PVA) hydrogels were prepared as oxygen-releasing materials ${ }^{89}$. PVP and PVA were crosslinked using gamma-ray irradiation, in which glucose oxidase and peroxidase enzymes were immobilized to generate oxygen. Materials that provide well-oxygenated environments support proper wound healing. Necrosis is a common issue associated with biomaterials in the treatment of chronic wounds. Polymer oxygen-generating (POG) films have been used to minimize necrosis by incorporating SPO into films of PLGA (Fig. 6). Figure 6 shows the results from a study that involved oxygenreleasing polymer films to reduce hypoxia in induced necrosis and support wound healing. In this study, rectangular flaps were created on the backs of nude mice, which were categorized into two groups ${ }^{51}$. One group received pure PLGA films, and the other group received 

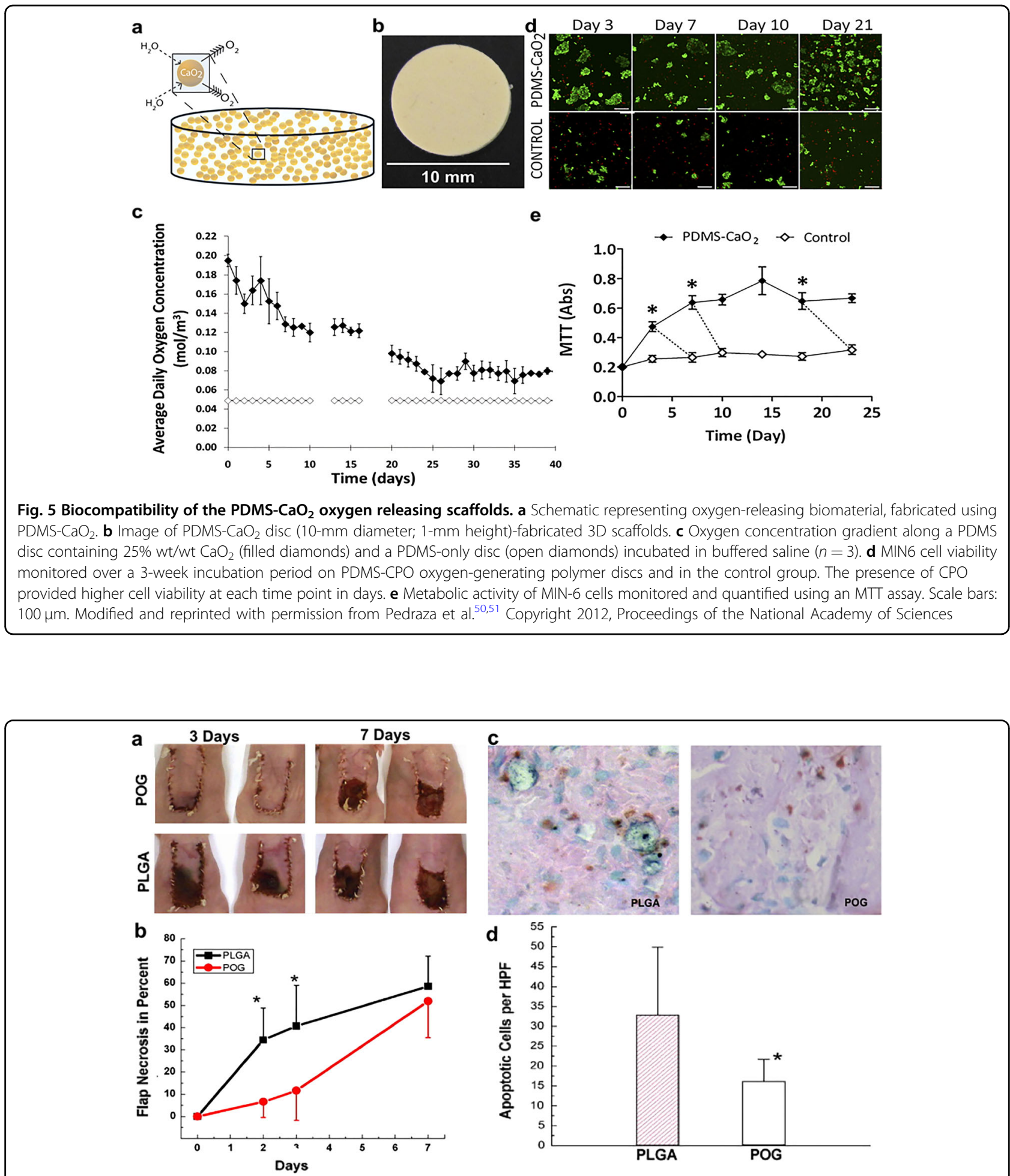

Fig. 6 Sodium percarbonate-based oxygen generating films to help reduce flap necrosis in wounds. a The effect of incorporation of sodium percarbonate nanoparticles for polymer oxygen-generating (POG) films to reduce flap necrosis. $\mathbf{b}$ Oxygen release dynamics in the engineered SPOcontaining POG films. $\mathbf{c}$ Histology staining of the dermis after 3 days showing apoptosis-positive cells with brown nuclei. Evaluation of apoptosis after 3 days: representative sections of the dermis showing apoptosis-positive cells with brown nuclei (nuclei counterstained with methyl green). $\mathbf{d}$ Data show a significantly higher apoptotic population in the pure PLGA section compared to the POG group $(n=7, p=0.30)$. Modified and reprinted with permission from Harrison et al..$^{51}$ Copyright 2007, Elsevier 
POG films. Flap necrosis was significantly less in the POG film-treated wounds than in the pure PLGA films (Fig. 6) ${ }^{51}$. Based on these findings, these technologies are advantageous and highly translatable in a series of wound healing applications.

\section{Bone tissue engineering}

The development of ideal barrier membranes with appropriate porosity and bioactivity is essential for the guided growth of bone in orthopedic and craniomaxillofacial applications ${ }^{90-92}$. A bone tissue engineering scaffold must be osteoconductive, porous, and biodegradable to support the attachment and proliferation of bone cells and encourage bone formation ${ }^{93-95}$. Furthermore, the blood supply must be compatible with artificial scaffolds to promote new tissue growth and healing ${ }^{96}$. Recently, a direct-write assembly (robocasting) technique was introduced to create porous scaffolds for bone regeneration. Compared to conventional approaches (e.g., freeze drying, gas foaming and electrospinning), this technique enables easier fabrication of complex structures $^{97,98}$. Figure 7 shows the results from a study in which a biphasic calcium phosphate scaffold was fabricated with $60 \%$ hydroxyapatite (HA) and $40 \%$ beta-tricalcium phosphate ( $\beta$-TCP) (Fig. 7$)^{99}$. The scaffold was then coated with polycaprolactone (PCL) and CPO incorporated. Once the scaffold was submerged in culture medium, oxygen was generated and released. The 10-day oxygen-release kinetics analysis showed no indication of a burst of oxygen (Fig. 7) ${ }^{99}$. Osteoblasts were then seeded onto the scaffold and cultured for up to 7 days. Staining with 3-(4,5-dimethylthiazol-2-yl)-2,5-diphenyltetrazolium bromide (MTT) and dialkylcarbocyanine demonstrated that the oxygenreleasing scaffolds did not damage the cells (Fig. 7).

Although oxygen supply is important, the uneven oxygen distribution within 3D scaffolds can create issues in the mineralization process during bone formation ${ }^{100}$. To study this aspect, oxygen levels were monitored for a static 3D culture system with mouse osteoblasts for 7 days. The results showed that the central part of the scaffold had significantly lower levels of oxygen compared to the outer parts of the scaffold. The findings of the study suggested that implementing oxygen-releasing scaffolds supported homogeneous oxygen tension. Therefore, scaffolds enriched with oxygen-releasing materials are expected to provide an environment to facilitate osteogenic differentiation of MSCs and other precursors, leading to homogeneous vascularization in vivo. These strategies can also benefit targeting hypoxia responses that can arise in bone tissue engineering or musculoskeletal regenerative applications

\section{Muscle regeneration}

There are a plethora of diseases and conditions that can cause muscle tissue damage or degeneration. Trauma or tumor formation often causes muscular tissue damage. Ischemia and ischemia-reperfusion injury negatively affect the recovery of damaged muscles and tissue regeneration ${ }^{101}$. Hyperbaric oxygen therapy has previously been used to treat these conditions; however, this approach was not an effective therapy ${ }^{102}$. An oxygen-releasing biomaterial, sodium percarbonate (SPO), has been used for skeletal muscle repair ${ }^{103}$. In this study, SPO particles were added at concentrations of 0,1 , and $10 \mathrm{mg} / \mathrm{mL}$ in Dulbecco's Modified Eagle's Medium (DMEM). The oxygen generation, hydrogen peroxide content, and the consequential $\mathrm{pH}$ changes were monitored. The dissolved oxygen concentration was determined by obtaining readings using a fluorescence plate reader instrument. SPO was tested in vitro for its oxygen-releasing properties and biocompatibility. In an aqueous environment, SPO was shown to be an in situ oxygen-releasing material with high biocompatibility. This oxygen-releasing reagent was then injected into ischemic muscles in rats, which resulted in significant improvements in limb muscle regeneration ${ }^{103}$. In a similar application, SPO particles were incorporated into electrospun nanofibers. Then, rat muscle precursor cells were cultured in these scaffolds under hypoxic environments in vitro. The oxygenreleasing nanofiber mesh yielded improved viability and differentiation $^{34,103}$.

Calcium peroxide has also been studied as a particulate oxygen-generating (POG) material with applications in enhanced muscle regeneration. In this approach, SPO and $\mathrm{CPO}$ were used in combination to engineer oxygenreleasing materials for tissue regeneration ${ }^{104}$. Skeletal muscle tissue was selected due to its high oxygen demand and dependency. The primary muscle tissues were isolated from rats and used in an in vitro hypoxic skeletal muscle injury model. The function of the engineered muscle tissue was analyzed before and after POG injection. The researchers injected the POG materials into the injured muscles of rats in the in vivo model. The histology experiments were performed for the recovering tissue after $48 \mathrm{~h}$. The results revealed that the injection of POG created an environment that was conducive to muscle regeneration and functionality ${ }^{104}$. These oxygen-releasing biomaterials have been proven to effectively stimulate muscle recovery and restore muscle function.

\section{Intervertebral disc regeneration}

Neck and lower back pain and discomfort are commonly associated with intervertebral disc degeneration. The current treatments, such as corticosteroid injections, surgeries, and cell-based therapies, have been shown to be ineffective. Most treatments are aimed at solely alleviating the pain instead of treating the degenerated disc. Similarly, most new cell-based strategies are in early stages and may not be compatible with all patients ${ }^{105}$. Recently, 
a

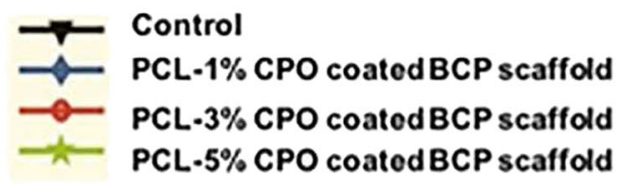

b

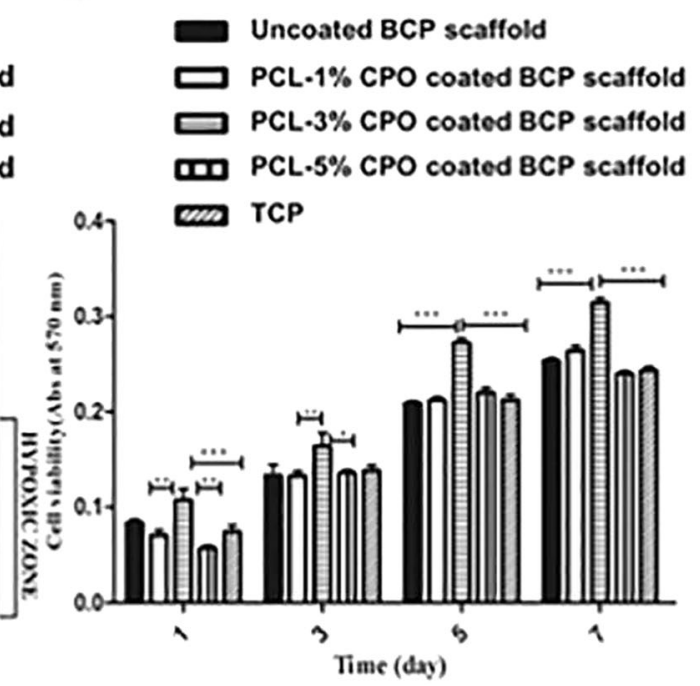

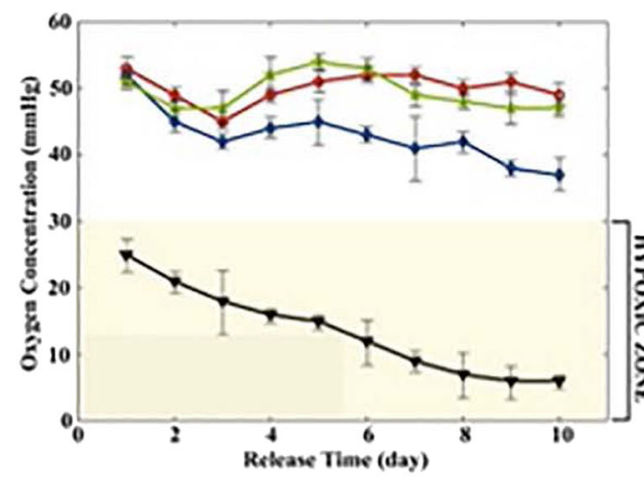

C 3D-printed oxygen releasing scaffolds

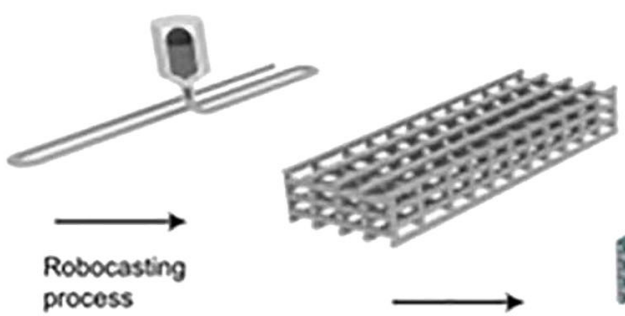

$30 \mathrm{BCP}$

Scaffolds

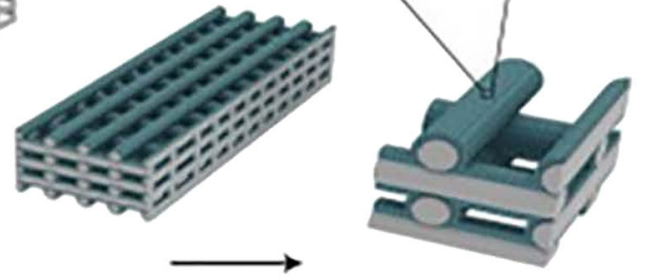

PCLCPO Coated 3D-BCP

Scaffolds

d
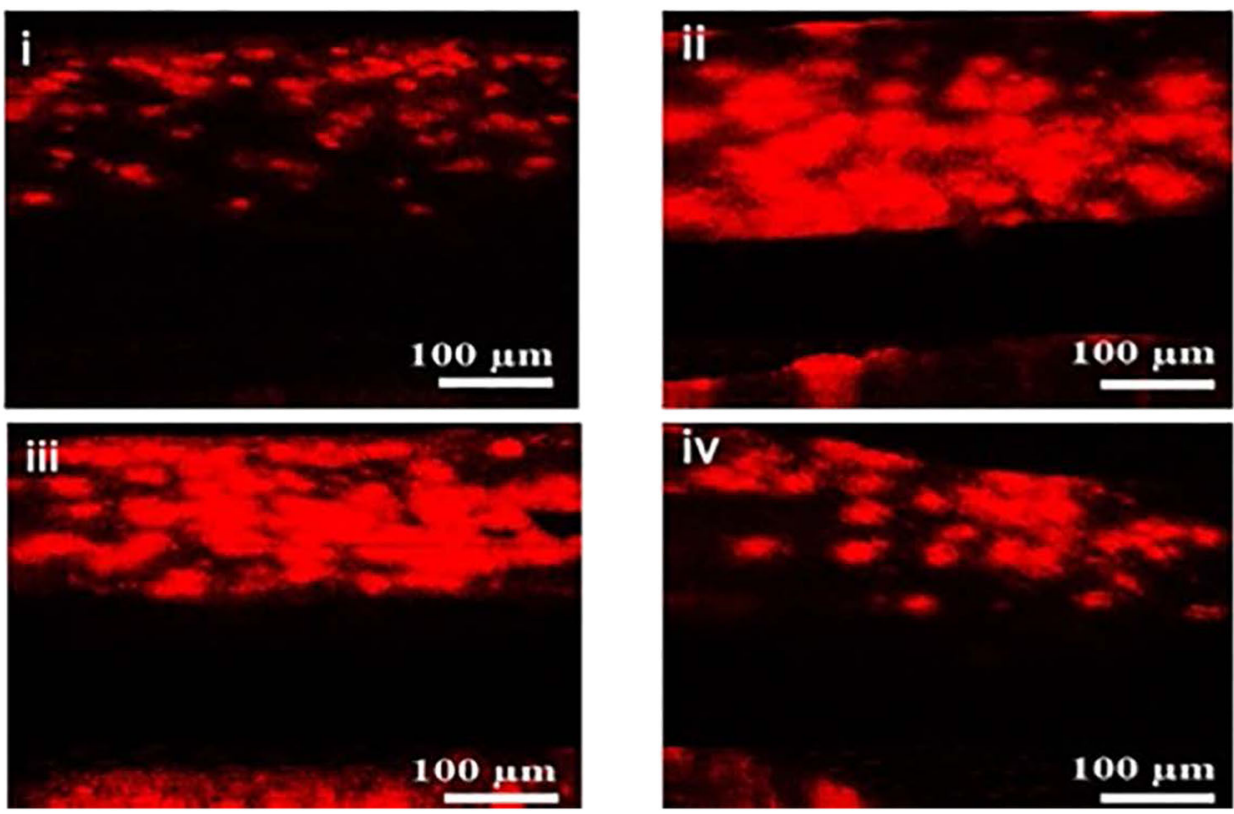

Fig. 7 Oxygen concentration and corresponding cell viability of osteoblasts on the scaffolds with varying concentrations of calcium peroxide (CPO). a Oxygen concentration in the control group and in the 1, 3, and $5 \%(\mathrm{w} / \mathrm{v})$ CPO-coated PCL scaffolds. b Cell viability of the osteoblasts on the CPOcoated scaffolds on days 1, 3, 5, and 7. Higher cell viability was observed for 3\% (w/v) CPO-coated scaffolds. (c) Fabrication process of a 3D printed scaffold for bone regeneration using 3D printing. $\mathbf{d}$ Laser confocal microscopy images of osteoblast cells on (i) an uncoated BCP scaffold, (ii), (iii), and (iv) CPO-PCL BCP scaffolds coated with 1,3, and 5\% CPO, respectively. Modified and reprinted with permission from Touri M. et al. ${ }^{99}$ Copyright 2018, Elsevier 
oxygen-releasing biomaterials have been shown to regenerate intervertebral discs. Inadequate nutrient and oxygen supply to disc cells, or nucleus pulposus (NP) cells, is one of the main causes of disc degeneration. Lack of oxygen prevents NP cells from synthesizing and preserving the extracellular cell matrix in the discs, leading to disc degeneration ${ }^{105}$. To address this problem, alginatebased scaffolds were prepared in combination with different concentrations $(2.5 \%, 5 \%$, and $10 \% \mathrm{w} / \mathrm{v})$ of perfluorotributylamine (PFTBA) to reduce disc degeneration ${ }^{106}$. Using PFTBA as an oxygen regulator, in vitro and in vivo studies were conducted. Figure 8 shows in vitro cell culture studies under hypoxic conditions produced an increase in the synthesis of ECM components (aggrecan, collagen II) for NP cells. Increased GAG expression in these cells occurred in $2.5 \%(\mathrm{w} / \mathrm{v})$ PFTBA-alginate scaffolds. The expression of these components was observed in normal NP cells, and the loss of their expression was observed in disc degeneration. Moreover, PFTBA at a $2.5 \%(\mathrm{w} / \mathrm{v})$ concentration supported NP cell survival and proliferation ${ }^{106}$. An intervertebral disc degeneration model was used in mice for the in vivo experiments. The mice that were injected with $2.5 \%(\mathrm{w} / \mathrm{v})$ PFTBA-alginate scaffolds and NP mouse cells showed alleviated disc degeneration. Specifically, the scaffolds supported the restoration of disc height and extracellular matrix components. These results were determined based on the disc high index (DHI) analyzed through micro-CT scanning and immunofluorescence studies for aggrecan and collagen II expression (Fig. 8) ${ }^{106}$.

\section{Other tissue engineering applications}

With a myriad of highly vascularized tissues, oxygenreleasing biomaterials are highly applicable in treating many forms of diseased or damaged tissues. For instance, perfluorocarbon-infused oxygen-generating polymers are strategies used in treating highly sensitive hypoxic tumors ${ }^{107}$. Oxygen-releasing biomaterials have also been used in neural stem cell engineering. Perfluorocarbons in conjugation with methacrylamide chitosan were found to promote the differentiation and growth of neural stem/ progenitor cells ${ }^{108}$. In plastic surgery, oxygen-generating polymer microspheres have been previously utilized to improve the efficiency of fat transplantation ${ }^{109}$. Autologous transplantation of fat is common in plastic surgeries, but a high rate of resorption has prevented this technique from practice until the introduction of oxygenreleasing materials. Adipose-derived stem cells (ASCs) have been used with oxygen-releasing microspheres for the transplantation of fat. The oxygen-releasing microspheres supplied oxygen to the ASCs where diffusion limitations interfered with adequate levels of oxygen. The in vivo results in rat models of this study demonstrated a significantly higher survival rate 2 weeks at postoperation.
The ASCs that survived were metabolically active in adipocyte angiogenesis, which improved the success of the fat transplantation ${ }^{109}$. Another tissue that is metabolically active with high oxygen demands is the liver. Hepatocytes of the liver are metabolically active cells but have limitations in oxygen diffusion in organ-sized constructs ${ }^{110}$. The incorporation of fluorocarbon-based oxygen-releasing systems has proven to effectively increase cell metabolic activity and proliferation ${ }^{110}$. For example, a collagen matrix included perflubron as an oxygen-release component ${ }^{110}$. The results of this study demonstrated an increase in the oxygen concentration in tissue cultures up to six times. These applications demonstrate that oxygenreleasing biomaterials have exceptional value for the repair and regeneration of tissues and can potentially bring tissue engineering approaches closer to clinical translation.

\section{Preventing biofilm formation}

Infections are one of the primary causes of biofilm formation on tissues surrounding implants in vivo. Consequently, biofilms produce an unfavorable environment for implant-tissue integration and require the implant to be removed and replaced ${ }^{111}$. Recent approaches to prevent biofilm formation use methods that involve modifying the surface of these implants with polymers, such as polyethylene glycol (PEG), which have anti-adhesive and antibacterial properties. Other approaches include coating the surfaces of implants with positively charged antimicrobial polymers and incorporating bleaching agents $^{112}$. However, these modifications result in poor tissue integration in vivo. Furthermore, the long-term in vivo use of the implants leads to adsorption of plasma proteins on the surface of the implants. This process causes the inactivation of coated antimicrobial properties. Thus, these modifications are tailored for short-term applications ${ }^{113}$. Novel approaches must involve biomaterials that eliminate biofilm formation and support satisfactory implant-tissue integration for long-term application. Recent studies employ oxygen-releasing biomaterials, of which the byproducts (e.g., oxygen radicals) act as antimicrobial agents with low to no toxicity. An electrospinning method was used to create oxygenreleasing PCL nanofibers with different concentrations of calcium peroxide $(1,5 \text {, and } 10 \% \mathrm{w} / \mathrm{v})^{113}$.

In addition, ascorbic acid has been incorporated into these nanofibers to eliminate the toxic effects of $\mathrm{CPO}$ byproducts and support human osteoblast (hFOB 1.19) viability. The antimicrobial properties of the oxygenreleasing nanofibers were evaluated by an MTS assay, in which oxygen-releasing nanofibers $(10 \%(\mathrm{w} / \mathrm{v})$ calcium peroxide-containing PCL nanofibers) were incubated with Escherichia coli (E. coli) or Staphylococcus epidermidis (S. epidermidis) strains. A Kirby-Bauer test was performed 


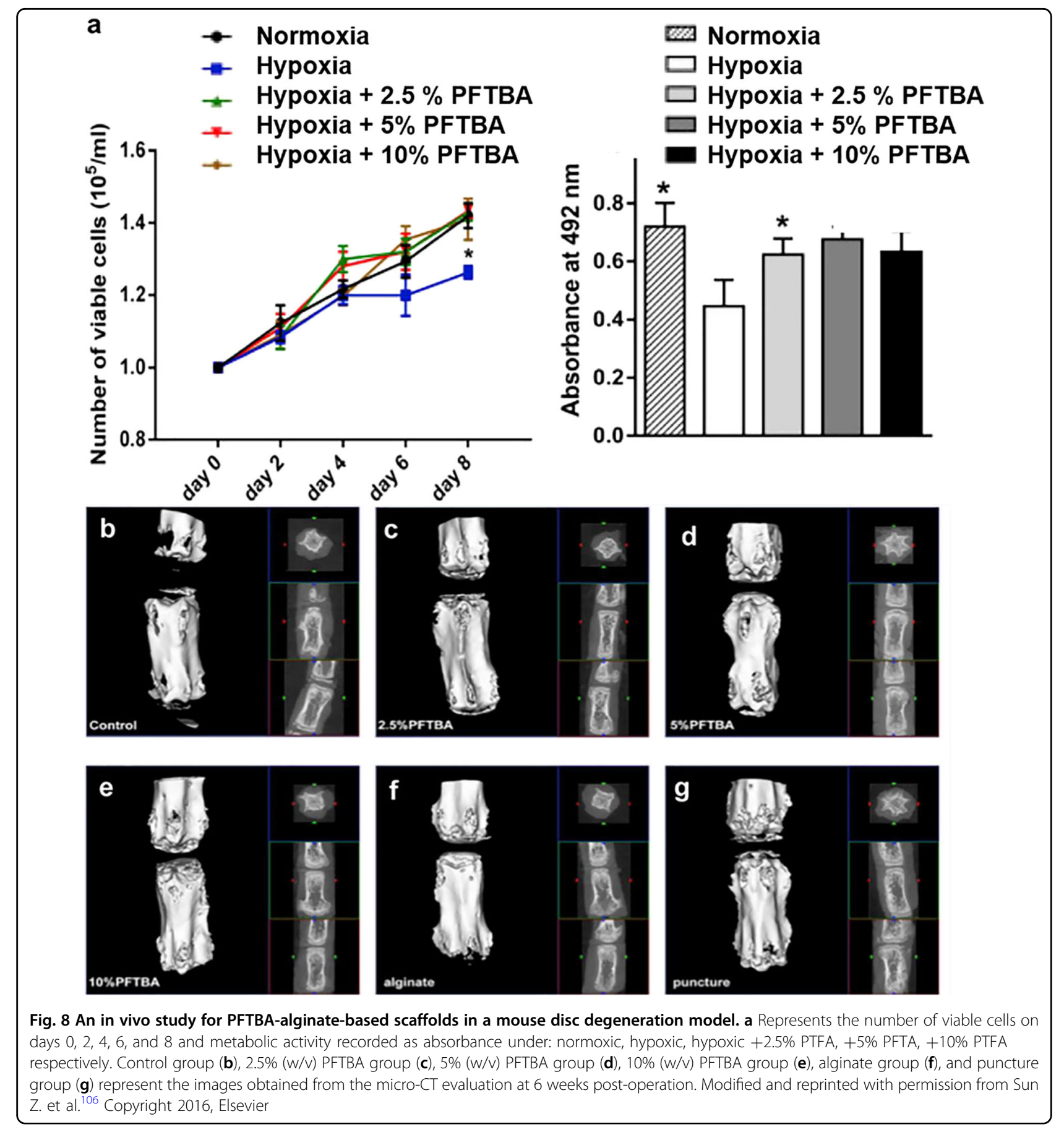

for $E$. coli growing on an agar plate to evaluate the microbial activity of the oxygen-releasing PCL nanofibers. The results demonstrated that a $10 \%(\mathrm{w} / \mathrm{v})$ calcium peroxide addition in the PCL nanofibers eliminated E. coli and S. epidermidis growth by 95 and $90 \%$, respectively. An inhibition zone formed around the antibiotic nanofibers that had been placed on the agar plates. The 2D seeding of human osteoblasts on calcium peroxide-PCL nanofibers resulted in short-term toxicity during the first day of incubation. This toxicity resulted from the initial rapid release of CPO from the nanofibers. However, the viability of the osteoblasts increased after four days of incubation. Greater viability was observed in the condition involving the integration of ascorbic acid within the calcium peroxide nanofibers. In orthopedic implants, the application of such nanofibers can prevent the bacterial formation and promote integration into the existing bone tissue. 


\section{Conclusions and future directions}

Tissue engineering approaches have been successful in formulating strategies to support the formation of vasculature in $3 \mathrm{D}$ constructs for the repair and regeneration of tissues. The synthesis of oxygen-releasing materials enhances these modern methodologies and addresses the high oxygen demands in tissue constructs. Oxygenreleasing biomaterials in the $3 \mathrm{D}$ encapsulation of cells offers an environment that meets the high oxygen demand posttransplantation in vivo. Many oxygenreleasing materials incorporate solid peroxides, liquid peroxides, and fluorinated compounds that decompose and release oxygen ${ }^{114}$.

Among many studies, calcium peroxide has been demonstrated to be the most effective inorganic solid compound for oxygen generation ${ }^{59}$. As discussed, for a controlled rate of reaction, calcium peroxide can be incorporated into hydrophobic polymers. The controlled and sustained presence of oxygen is imperative for the first few weeks to promote cell differentiation and tissue healing ${ }^{52,115}$. The use of liquid peroxides (e.g., hydrogen peroxide) as oxygen carriers has also shown considerable potential in tissue engineering applications. Specifically, the high solubility of hydrogen peroxide can improve the oxygen-carrying capacity of a polymer ${ }^{11}$. In addition, fluorinated compounds, such as perfluorocarbons, have shown promising performances as oxygen carriers and in supporting cell viability ${ }^{116}$. Overall, oxygen-releasing biomaterials have been widely explored in cardiovascular tissue engineering, islet transplantation, bone regeneration, muscle regeneration, and wound healing applications $^{51}$. This vast array of fields also includes intervertebral disc regeneration ${ }^{106}$ and preventing the formation of biofilms ${ }^{113}$.

The other prospects for oxygen-releasing polymers include drug delivery, preventing necrotic cell death, and tissue rehabilitation. Oxygen-releasing biomaterials can offer therapeutic and functional benefits during tissue regeneration and remodeling. In synthetically bioengineered implants, vascularization and tissue ingrowth are necessary for integration in vivo. The studies in this review have revealed that an oxygen-rich environment can encourage integration with the host tissue. This particular aspect is applicable for tissue integration around prostheses and orthotic implants. Moreover, the applications support sufficient nutrient and oxygen diffusion in vivo for viable and functional tissue constructs. In further developments, systematic in vivo studies and histological analyses are necessary to validate these specific strategies. In these biomaterials, controlled oxygen release is also applicable for drug delivery processes ${ }^{117}$. Based on previous applications, hydrophobic barriers can assist in facilitating the controlled and targeted delivery of pharmaceutical products. The versatility of oxygen- releasing biomaterials can give rise to next-generation viable and functional tissue constructs. As this area of research continues to grow, oxygen-releasing biomaterials can advance the translation of engineered constructs from the lab bench to patient care.

\section{Acknowledgements}

This work was funded by the University of Massachusetts Lowell start-up funds. M.A.N. was partially supported by a scholarship from the Urban Massachusetts Alliance for Minority Participation (UMLSAMP) program.

\section{Author details}

${ }^{1}$ Biomedical Engineering and Biotechnology Program, University of Massachusetts Lowell, One University Avenue, Lowell, MA 01854, USA. ${ }^{2}$ Department of Chemical Engineering, University of Massachusetts Lowell, One University Avenue, Lowell, MA 01854, USA. ${ }^{3}$ Department of Biomedical Engineering, University of Massachusetts Lowell, One University Avenue, Lowell, MA 01854, USA. "4Department of Surgery, University of Massachusetts Medical School, 55 Lake Avenue North, Worcester, MA 01605, USA

Authors' contributions

G.C.-U. conceived of the study. S.S., X.W., D.L., M.A.N., and G.C.-U. wrote, revised, and edited the paper.

Conflict of interest

The authors declare that they have no conflict of interest.

\section{Publisher's note}

Springer Nature remains neutral with regard to jurisdictional claims in published maps and institutional affiliations.

Received: 24 May 2019 Revised: 18 July 2019 Accepted: 27 August 2019. Published online: 8 November 2019

\section{References}

1. United States Department of Health And Human Services (U. D. o. H. a. H.) Organ Donation Statistics, https://www.organdonor.gov/statistics-stories/ statistics.html (2017)

2. Slaughter, B. V., Khurshid, S. S., Fisher, O. Z., Khademhosseini, A. \& Peppas, N. A. Hydrogels in regenerative medicine. Adv. Mater. 21, 3307-3329 (2009).

3. Wynn, J. J. \& Alexander, C. E. Increasing organ donation and transplantation: the US experience over the past decade. Transpl. Int. 24, 324-332 (2011).

4. Hsieh, H.-Y. et al. Gradient static-strain stimulation in a microfluidic chip for 3D cellular alignment. Lab. Chip. 14, 482-493 (2014).

5. Ahadian, S. et al. A contactless electrical stimulator: application to fabricate functional skeletal muscle tissue. Biomed. Microdevices. 15, 109-115 (2013).

6. Camci-Unal, G., Newsome, D., Eustace, B. K. \& Whitesides, G. M. Fibroblasts Enhance Migration of Human Lung Cancer Cells in a Paper-Based Coculture System. Adv. Healthc. Mater. 5, 641-647 (2016).

7. Suvarnapathaki, S., Nguyen, M. A., Wu, X., Nukavarapu, S. P. \& Camci-Unal, G. Synthesis and characterization of photocrosslinkable hydrogels from bovine skin gelatin. RSC. Adv. 9, 13016-13025 (2019).

8. Elliott, M. J. et al. Stem-cell-based, tissue engineered tracheal replacement in a child: a 2-year follow-up study. Lancet 380, 994-1000 (2012).

9. Park, J. H. et al. Experimental tracheal replacement using 3-dimensional bioprinted artificial trachea with autologous epithelial cells and chondrocytes. Sci. Rep. 9, 2103 (2019).

10. Ott, H. C. et al. Regeneration and orthotopic transplantation of a bioartificial lung. Nat. Med. 16, 927-933 (2010).

11. Camci-Unal, G., Alemdar, N., Annabi, N. \& Khademhosseini, A. Oxygenreleasing biomaterials for tissue engineering. Polym. Int. 62, 843-848 (2013).

12. Novosel, E. C., Kleinhans, C. \& Kluger, P. J. Vascularization is the key challenge in tissue engineering. Adv. Drug. Deliv. Rev. 63, 300-311 (2011). 
13. Wernike, E., et al. VEGF incorporated into calcium phosphate ceramics promotes vascularisation and bone formation in vivo. Eur. Cell. Mater. 19, 30-40 (2010).

14. Kang, Y. \& Chang, J. Channels in a porous scaffold: a new player for vascularization. Regen. Med. 13, 705-715 (2018).

15. Baranski, J. D. et al. Geometric control of vascular networks to enhance engineered tissue integration and function. Proc. Natl Acad. Sci. USA 110 7586-7591 (2013).

16. Oh, S. H., Ward, C. L., Atala, A., Yoo, J. J. \& Harrison, B. S. Oxygen generating scaffolds for enhancing engineered tissue survival. Biomaterials 30, 757-762 (2009).

17. Shin, M. et al. Endothelialized networks with a vascular geometry in microfabricated poly (dimethyl siloxane). Biomed. Microdevices. 6 269-278 (2004)

18. Camci-Unal, G., Annabi, N., Dokmeci, M. R., Liao, R. \& Khademhosseini, A. Hydrogels for cardiac tissue engineering. NPG Asia Mater. 6, e99 (2014).

19. Camci-Unal, G., Cuttica, D., Annabi, N., Demarchi, D. \& Khademhosseini, A Synthesis and characterization of hybrid hyaluronic acid-gelatin hydrogels. Biomacromolecules 14, 1085-1092 (2013).

20. Pashneh-Tala, S., MacNeil, S. \& Claeyssens, F. The tissue-engineered vascular graft-past, present, and future. Tissue Eng. Part B Rev. 22 68-100 (2015).

21. Camci-Unal, G. \& Khademhosseini, A. Biomaterials that breathe. Chem. Ind. 77, 28-30 (2013).

22. Lewis, M. C, MacArthur, B. D. Malda, J. Pettet, G. \& Please, C. P. Heterogeneous proliferation within engineered cartilaginous tissue: the role of oxygen tension. Biotechnol. Bioeng. 91, 607-615 (2005).

23. Brey, E. M. \& Patrick, C. Tissue engineering applied to reconstructive surgery. IEEE Eng. Med. Biol. Mag. 19, 122-125 (2000).

24. Radisic, M. et al. Medium perfusion enables engineering of compact and contractile cardiac tissue. Am. J. Physiol. Heart Circ. Physiol. 286, H507-H516 (2004).

25. Carrier, R. L. et al. Cardiac tissue engineering: cell seeding, cultivation parameters, and tissue construct characterization. Biotechnol. Bioeng. 64, 580-589 (1999).

26. Zimmermann, W. H. et al. Engineered heart tissue grafts improve systolic and diastolic function in infarcted rat hearts. Nat. Med. 12, 452-458 (2006).

27. Vunjak-Novakovic, G. et al. Challenges in cardiac tissue engineering. Tissue Eng. Part B Rev. 16, 169-187 (2009).

28. Camci-Unal, G. et al. Hydrogel surfaces to promote attachment and spreading of endothelial progenitor cells. J. Tissue Eng. Regen. Med. 7, 337-347 (2013).

29. Hancock, M. J., Piraino, F., Camci-Unal, G., Rasponi, M. \& Khademhosseini, A Anisotropic material synthesis by capillary flow in a fluid stripe. Biomaterials 32, 6493-6504 (2011).

30. Bauer, M. et al. Adult cardiac progenitor cell aggregates exhibit survival benefit both in vitro and in vivo. PLOS ONE 7, e50491 (2012).

31. Liau, B., Christoforou, N., Leong, K. W. \& Bursac, N. Pluripotent stem cellderived cardiac tissue patch with advanced structure and function. Biomaterials 32, 9180-9187 (2011).

32. Radisic, M., Marsano, A., Maidhof, R., Wang, Y. \& Vunjak-Novakovic, G. Cardiac tissue engineering using perfusion bioreactor systems. Nat. Protoc. $\mathbf{3}$, 719-738 (2008).

33. Dew, L., MacNeil, S. \& Chong, C. K. Vascularization strategies for tissue engineers. Regen. Med. 10, 211-224 (2015).

34. Hoganson, D. M., Pryor, H. I. \& Vacanti, J. P. Tissue engineering and organ structure: a vascularized approach to liver and lung. Pediatr. Res. 63, 520-526 (2008).

35. Suvarnapathaki, S. et al. Generation of cell-laden hydrogel microspheres using 3D printing-enabled microfluidics. J. Mater. Res. 33, 2012-2018 (2018)

36. Laschke, M. W. et al. Angiogenesis in tissue engineering: breathing life into constructed tissue substitutes. Tissue Eng. 12, 2093-2104 (2006).

37. Folkman, J. \& Klagsbrun, M. Angiogenic factors. Science 235, $442-447$ (1987)

38. Griffith, C. K. et al. Diffusion limits of an in vitro thick prevascularized tissue. Tissue Eng. 11, 257-266 (2005).

39. Sekiya, S., Shimizu, T., Yamato, M., Kikuchi, A. \& Okano, T. Bioengineered cardiac cell sheet grafts have intrinsic angiogenic potential. Biochem. Biophys. Res. Commun. 341, 573-582 (2006).

40. Hendrickx, B., Vranckx, J. J. \& Luttun, A. Cell-based vascularization strategies for skin tissue engineering. Tissue Eng. Part B Rev. 17, 13-24 (2010).
41. Ma, P. X. \& Choi, J. W. Biodegradable polymer scaffolds with well-defined interconnected spherical pore network. Tissue Eng. 7, 23-33 (2001).

42. Liu, X., Won, Y. \& Ma, P. X. Surface modification of interconnected porous scaffolds. J. Biomed. Mater. Res. A 74, 84-91 (2005).

43. Zhu, M., et al. Fabrication of highly interconnected porous silk fibroin scaffolds for potential use as vascular grafts. Acta Biomater. 10, 2014-2023 (2014).

44. Luciani, A., Coccoli, V., Orsi, S., Ambrosio, L. \& Netti, P. A. PCL microspheres based functional scaffolds by bottom-up approach with predefined microstructural properties and release profiles. Biomaterials 29, 4800-4807 (2008).

45. McQuilling, J. P., Sittadjody, S., Pendergraft, S., Farney, A. C. \& Opara, E. C. Applications of particulate oxygen-generating substances (POGS) in the bioartificial pancreas. Biomater. Sci. 5, 2437-2447 (2017).

46. Ward, K. R., Huvard, G. S., McHugh, M., Mallepally, R. R. \& Imbruce, R. Chemical oxygen generation. Respir. Care. 58, 184-195 (2013).

47. Opara, E. C. \& Harrison, B. S. Co-encapsulation of live cells with oxygengenerating particles. Wake Forest University Health Sciences. U.S. Patent 9,775,866 (2017).

48. Ng, S. M., Choi, J. Y., Han, H. S., Huh, J. S. \& Lim, J. O. Novel microencapsulation of potential drugs with low molecular weight and high hydrophilicity: hydrogen peroxide as a candidate compound. Int. J. Pharm. 384, 120-127 (2010).

49. Li, Z., Guo, X. \& Guan, J. An oxygen release system to augment cardiac progenitor cell survival and differentiation under hypoxic condition. Biomaterials 33, 5914-5923 (2012).

50. Pedraza, E., Coronel, M. M., Fraker, C. A., Ricordi, C. \& Stabler, C. L. Preventing hypoxia-induced cell death in beta cells and islets via hydrolytically activated, oxygen-generating biomaterials. Proc. Natl Acad. Sci. USA 109, 4245-4250 (2012).

51. Harrison, B. S., Eberli, D., Lee, S. J., Atala, A. \& Yoo, J. J. Oxygen producing biomaterials for tissue regeneration. Biomaterials 28, 4628-4634 (2007).

52. Steg, $\mathrm{H}$. et al. Control of oxygen release from peroxides using polymers. J. Mater. Sci. Mater. Med. 26, 1-4 (2015).

53. Fraker, C. A., Mendez, A. J. \& Stabler, C. L. Complementary methods for the determination of dissolved oxygen content in perfluorocarbon emulsions and other solutions. J. Phys. Chem. B. 115, 10547-10552 (2011).

54. Chandra, P. K. et al. Peroxide-based oxygen generating topical wound dressing for enhancing healing of dermal wounds. Wound Repair Regen. 23, 830-841 (2015).

55. Waite, A. J., Bonner, J. S. \& Autenrieth, R. Kinetics and stoichiometry of oxygen release from solid peroxides. Environ. Eng. Sci. 16, 187-199 (1999).

56. Haynes, W. M. CRC Handbook of Chemistry and Physics (CRC press, 2014).

57. O'Neil, M., Smith, A., Heckelman, P. \& Budavari, S. The Merck Index-An Encyclopedia of Chemicals, Drugs, and Biologicals. Whitehouse Station, NJ: Merck and Co. Inc 767, 4342 (2001).

58. Borden, R. C., Goin, R. T. \& Kao, C. M. Control of BTEX migration using a biologically enhanced permeable barrier. Groundw. Monit. R. 17, 70-80 (1997).

59. Farris, A. L., Rindone, A. N. \& Grayson, W. L. Oxygen delivering biomaterials for tissue engineering. J. Mater. Chem. B 4, 3422-3432 (2016).

60. Gholipourmalekabadi, M., Zhao, S., Harrison, B. S., Mozafari, M. \& Seifalian, A. M. Oxygen-generating biomaterials: a new, viable paradigm for tissue engineering. Trends Biotechnol. 34, 1010-1021 (2016).

61. Wang, H., Zhou, H., Liu, H., Yuan, T. \& Li, X. Controlled release oxygen using polymers. International Conference on Manufacturing Science and Engineering (ICMSE). 1698-1701 (Atlantis Press, 2015).

62. Schmidtke, T., White, D. \& Woolard, C. Oxygen release kinetics from solid phase oxygen in Arctic Alaska. J. Hazard. Mater. 64, 157-165 (1999).

63. Folkman, J. \& Hochberg, M. Self-regulation of growth in three dimensions. J. Exp. Med. 138, 745-753 (1973).

64. Abdi, S. I. H., Ng, S. M. \& Lim, J. O. An enzyme-modulated oxygen-producing micro-system for regenerative therapeutics. Int. J. Pharm. 409, 203-205 (2011).

65. Riess, J. G. \& Krafft, M. P. Fluorinated materials for in vivo oxygen transport (blood substitutes), diagnosis and drug delivery. Biomaterials 19, 1529-1539 (1998).

66. Riess, J. G. Highly fluorinated systems for oxygen transport, diagnosis and drug delivery. Colloids Surf. A: Physicochemical Eng. Asp. 84, 33-48 (1994).

67. Inayat, M. S. et al. Oxygen carriers: a selected review. Transfus. Apher. Sci. 34, 25-32 (2006). 
68. Chin, K., Khattak, S. F., Bhatia, S. R. \& Roberts, S. C. Hydrogel-perfluorocarbon composite scaffold promotes oxygen transport to immobilized cells. Biotechnol. Prog. 24, 358-366 (2008).

69. Kranke, P. et al. Hyperbaric oxygen therapy for chronic wounds. Cochrane Database Syst. Rev. 6, 1-57 (2015).

70. Petsche Connell, J., Camci-Unal, G., Khademhosseini, A. \& Jacot, J. G. Amniotic fluid-derived stem cells for cardiovascular tissue engineering applications. Tissue Eng. Part B. Rev. 19, 368-379 (2013).

71. Wu, X., Suvarnapathaki, S., Walsh, K. \& Camci-Unal, G. Paper as a scaffold for cell cultures: Teaching an old material new tricks. MRS Commun. 8, 1-14 (2018).

72. Lantigua, D., Kelly, Y. N., Unal, B. \& Camci-Unal, G. Engineered paper-based cell culture platforms. Adv. Healthc. Mater. 6, 1700619 (2017).

73. Seifu, D. G., Isimjan, T. T. \& Mequanint, K. Tissue engineering scaffolds containing embedded fluorinated-zeolite oxygen vectors. Acta Biomater. 7, 3670-3678 (2011).

74. Ryan, E. A. et al. Five-year follow-up after clinical islet transplantation. Diabetes 54, 2060-2069 (2005).

75. Menger, M. D. et al. Angiogenesis and hemodynamics of microvasculature of transplanted islets of Langerhans. Diabetes 38, 199-201 (1989).

76. Lau, J., Henriksnäs, J., Svensson, J. \& Carlsson, P.-O. Oxygenation of islets and its role in transplantation. Curr. Opin. Organ Transpl. 14, 688-693 (2009).

77. Montazeri, L. et al. Improvement of islet engrafts by enhanced angiogenesis and microparticle-mediated oxygenation. Biomaterials $\mathbf{8 9}$ 157-165 (2016)

78. Ochoa, M. et al. A paper-based oxygen generating platform with spatially defined catalytic regions. Sens. Actuators B Chem. 198, 472-478 (2014).

79. Patil, P. S. et al. Fluorinated methacrylamide chitosan hydrogels enhance collagen synthesis in wound healing through increased oxygen availability. Acta Biomater. 36, 164-174 (2016).

80. Broughton, G. 2nd, Janis, J. E. \& Attinger, C. E. The basic science of wound healing. Plast. Reconstr. Surg. 117, 12S-34S (2006).

81. Heng, M., Harker, J., Bardakjian, V. \& Ayvazian, H. Enhanced healing and costeffectiveness of low-pressure oxygen therapy in healing necrotic wounds: a feasibility study of technology transfer. Ostomy Wound Manag. 46, 52-60, 62 (2000)

82. Schreml, S. et al. Oxygen in acute and chronic wound healing. Br. J. Dermatol. 163, 257-268 (2010)

83. Gordillo, G. M. \& Sen, C. K. Evidence-based recommendations for the use of topical oxygen therapy in the treatment of lower extremity wounds. Int. J. Low. Extrem. Wounds 8, 105-111 (2009).

84. Thistlethwaite, K. R. et al. The effectiveness of hyperbaric oxygen therapy for healing chronic venous leg ulcers: A randomized, double-blind, placebocontrolled trial. Wound Repair Regen. 26, 324-331 (2018).

85. Sunkari, V. G. et al. Hyperbaric oxygen therapy activates hypoxia-inducible factor 1 (HIF-1), which contributes to improved wound healing in diabetic mice. Wound Repair Regen. 23, 98-103 (2015).

86. Tibbles, P. M. \& Edelsberg, J. S. Hyperbaric-oxygen therapy. N. Engl. J. Med. 334, 1642-1648 (1996)

87. Hary, G. B. \& Mainous, E. G. The treatment of radiation necrosis with hyperbaric oxygen (OHP). Cancer 37, 2580-2585 (1976).

88. Jeffcoate, W. J. \& Harding, K. G. Diabetic foot ulcers. Lancet 361, 1545-1551 (2003).

89. Song, N. E., Song, Y. R., Gwon, H. J., Lim, Y. M. \& Baik, S. H. Preparation and characterization of oxygen generating $(\mathrm{OG})$ hydrogels using $Y$-ray irradiation crosslinking. Macromol. Res. 20, 1137-1143 (2012).

90. Yaszemski, M. J., Payne, R. G., Hayes, W. C., Langer, R. \& Mikos, A. G. Evolution of bone transplantation: molecular, cellular and tissue strategies to engineer human bone. Biomaterials 17, 175-185 (1996).

91. Eppley, B. L., Pietrzak, W. S. \& Blanton, M. W. Allograft and alloplastic bone substitutes: a review of science and technology for the craniomaxillofacial surgeon. J. Craniofac. Surg. 16, 981-989 (2005).

92. Wu, X., Stroll, S., Lantigua, D., Suvarnapathaki, S. \& Camci-Unal, G. Eggshell particle-reinforced hydrogels for bone tissue engineering: an unconventional approach. Biomater. Sci. https://doi.org/10.1039/C9BM00230H (2019).

93. Karageorgiou, V. \& Kaplan, D. Porosity of 3D biomaterial scaffolds and osteogenesis. Biomaterials 26, 5474-5491 (2005).

94. Dahlin, C., Linde, A., Gottlow, J. \& Nyman, S. Healing of bone defects by guided tissue regeneration. Plast. Reconstr. Surg. 81, 672-676 (1988).

95. Camci-Unal, G., Laromaine, A., Hong, E., Derda, R. \& Whitesides, G. M. Biomineralization guided by paper templates. Sci. Rep. 6, 27693 (2016).
96. Bhattacharya, I., Ghayor, C. \& Weber, F. E. The use of adipose tissue-derived progenitors in bone tissue engineering-a review. Transfus. Med. Hemother. 43, 336-343 (2016).

97. Dejaco, A., Komlev, V. S., Jaroszewicz, J., Swieszkowski, W. \& Hellmich, C. Fracture safety of double-porous hydroxyapatite biomaterials. Bioinspir. Biomim. Nan 5, 24-36 (2016).

98. Russias, J. et al. Fabrication and in vitro characterization of three-dimensional organic/inorganic scaffolds by robocasting. J. Biomed. Mater. Res. A 83, 434-445 (2007).

99. Touri, M., Moztarzadeh, F., Osman, N. A. A., Dehghan, M. M. \& Mozafari, M. 3D-printed biphasic calcium phosphate scaffolds coated with an oxygen generating system for enhancing engineered tissue survival. Mater. Sci. Eng. C. 84, 236-242 (2018).

100. Volkmer, E. et al. Hypoxia in static and dynamic 3D culture systems for tissue engineering of bone. Tissue Eng. Part A. 14, 1331-1340 (2008).

101. Blaisdell, F. W. The pathophysiology of skeletal muscle ischemia and the reperfusion syndrome: a review. Cardiovasc. Surg. 10, 620-630 (2002).

102. Thom, S. R. Hyperbaric oxygen-its mechanisms and efficacy. Plast. Reconstr. Surg. 127, $131 \mathrm{~S}$ (2011).

103. Ward, C. L., Corona, B. T., Yoo, J. J., Harrison, B. S. \& Christ, G. J. Oxygen generating biomaterials preserve skeletal muscle homeostasis under hypoxic and ischemic conditions. PLOS ONE 8, e72485 (2013).

104. Ward, C. L. Oxygen generating materials for tissue restoration and regeneration (Wake Forest University, 2011).

105. Urban, J. P. \& Roberts, S. Degeneration of the intervertebral disc. Arthritis Res. Ther. 5, 120 (2003).

106. Sun, Z. et al. Effect of perfluorotributylamine-enriched alginate on nucleus pulposus cell: Implications for intervertebral disc regeneration. Biomaterials 82, 34-47 (2016)

107. Gao, S. et al. Oxygen-generating hybrid nanoparticles to enhance fluorescent/photoacoustic/ultrasound imaging guided tumor photodynamic therapy. Biomaterials 112, 324-335 (2017).

108. Li, H., Wijekoon, A. \& Leipzig, N. D. Encapsulated neural stem cell neuronal differentiation in fluorinated methacrylamide chitosan hydrogels. Ann Biomed. Eng. 42, 1456-1469 (2014).

109. Jung, D. W. et al. Improvement of fat transplantation: fat graft with adiposederived stem cells and oxygen-generating microspheres. Ann. Plast. Surg. 75, 463-470 (2015).

110. Nahmias, $Y$. et al. A novel formulation of oxygen-carrying matrix enhances liver specific function of cultured hepatocytes. FASEB J. 20 , 2531-2533 (2006)

111. Arciola, C. R., Campoccia, D., Speziale, P., Montanaro, L. \& Costerton, J. W. Biofilm formation in Staphylococcus implant infections. a review of molecular mechanisms and implications for biofilm-resistant materials. Biomaterials 33, 5967-5982 (2012).

112. Pavithra, D. \& Doble, M. Biofilm formation, bacterial adhesion and host response on polymeric implants—issues and prevention. Biomed. Mater. $\mathbf{3}$ 034003 (2008).

113. Wang, J. et al. Oxygen-generating nanofiber cell scaffolds with antimicrobial properties. ACS Appl. Mater. Interfaces 3, 67-73 (2010).

114. Lim, J. O., Huh, J. S., Abdi, S. I. H., Ng, S. M. \& Yoo, J. J. Functionalized biomaterials-oxygen releasing scaffolds. J. Biotechnol. Biomater. 5, 1 (2015).

115. Krishnan, R., Ko, D., Tucker, T. \& Opara, E. Strategies to combat hypoxia in encapsulated islet. Transplant. Surg. Curr. Res. 6, 1-10 (2016).

116. Gunatillake, P. A. \& Adhikari, R. Biodegradable synthetic polymers for tissue engineering. Eur. Cell. Mater. 5, 1-16 (2003).

117. Chien, Y. W. \& Lin, S. Drug delivery: Controlled release. Encycl. Pharm. Technol. 1. 811-833 (2002).

118. Yang, L., Zhu, L., Dong, W., Cao, Y. \& Rong, Z. Oxygen-generating scaffolds: a new strategy for bone tissue engineering. Bone 57, 322-323 (2013).

119. Mallepally, R. R., Parrish, C. C., Mc Hugh, M. A. \& Ward, K. R. Hydrogen peroxide filled poly (methyl methacrylate) microcapsules: potential oxygen delivery materials. Int. J. Pharm. 475, 130-137 (2014).

120. Coronel, M. M., Geusz, R. \& Stabler, C. L. Mitigating hypoxic stress on pancreatic islets via in situ oxygen generating biomaterial. Biomaterials 129, 139-151 (2017).

121. Lowe, K. C. Fluorinated blood substitutes and oxygen carriers. J. Fluor. Chem. 109, 59-65 (2001).

122. Budavari, S., et al. The Merck Index: An Encyclopedia of Chemicals, Drugs, and Biologicals, Whitehouse Station, NJ: Merck \& Co. Inc 450, 1674 (1996). 
123. Patnaik, P. Handbook of inorganic chemicals. vol 529 (McGraw-Hill, New York, 2003).

124. McKillop, A. \& Sanderson, W. R. Sodium perborate and sodium percarbonate: cheap, safe and versatile oxidising agents for organic synthesis. Tetrahedron 51, 6145-6166 (1995).

125. Winslow, R. M. \& Riess, G. Artificial Cells, Blood Substitutes, and Immobilization Biotechnology, California University of San Diego La Jolla, Volume 22, Number 4, (1994).

126. Shaffer, T., Wolfson, M., Greenspan, J., Rubenstein, S. \& Stern, R. Perfluorochemical liquid as a respiratory medium. Artif. Cells Blood Substit. Biotechnol. 22, 315-326 (1994).

127. Chang, S., Reppucci, V., Zimmerman, N. J., Heinemann, M.-H. \& Coleman, D. J. Perfluorocarbon liquids in the management of traumatic retinal detachments. Ophthalmology 96, 785-792 (1989).
128. Radisic, M. et al. Biomimetic approach to cardiac tissue engineering: oxygen carriers and channeled scaffolds. Tissue Eng. 12, 2077-2091 (2006).

129. Yokoyama, K., Yamanouchi, K. \& Suyama, T. Recent advances in a perfluorochemical blood substitute and its biomedical application. Life Chem. Rep. 2, 35-93 (1983).

130. Krafft, M. P. \& Riess, J. Stable highly concentrated fluorocarbon gels. Angew. Chem. Int. Ed. 33, 1100-1101 (1994).

131. Mathis, G., Leempoel, P., Ravey, J. C., Selve, C. \& Delpuech, J. J. A novel class of nonionic microemulsions: fluorocarbons in aqueous solutions of fluorinated poly (oxyethylene) surfactants. J. Am. Chem. Soc. 106 6162-6171 (1984).

132. Giulieri, F., Krafft, M. P. \& Riess, J. G. Stable flexible fibers and rigid tubules made from single-chain perfluoroalkylated amphiphiles. Angew. Chem. Int. Ed. 33, 1514-1515 (1994). 